
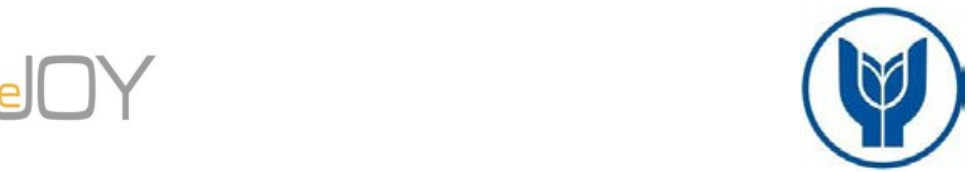

Sekmen, T., Doğan, E., Topuz, S. G. / Journal of Yasar University, 2020, 15/59, 544-559

\title{
Türkiye'de Kamu İç Borcunun Finansal Gelişme Üzerindeki Dışlama Etkisi
}

\section{The Crowding Out Effect of Domestic Public Debt on Financial Development in Turkey}

\author{
Taner SEKMEN, Eskişehir Osmangazi Üniversitesi, Türkiye, tsekmen@ogu.edu.tr \\ Orcid No: 0000-0002-0363-3765 \\ Esra DOĞAN, Eskişehir Osmangazi Üniversitesi, Türkiye, edogan@ogu.edu.tr \\ Orcid No: 0000-0002-9886-4186 \\ Seher Gülşah TOPUZ, Eskişehir Osmangazi Üniversitesi, Türkiye, stopuz@ogu.edu.tr \\ Orcid No: 0000-0002-7761-6255
}

\begin{abstract}
Öz: Finansal gelişmenin başta ekonomik büyüme olmak üzere birçok makroekonomik değişken üzerindeki etkisi yoğun bir şekilde araştırılmış olmasına rağmen finansal gelişmenin belirleyicilerine ilişkin ampirik kanıtlar oldukça sınırlıdır. Bu çalışma Türkiye’nin kamu iç borcunun finansal gelişme üzerinde herhangi anlamlı bir etkisinin olup olmadığını sorgulamaktadır. 1980-2017 döneminde kamu iç borçlanmasının finansal gelişme üzerindeki etkisine dair tahminler Gecikmesi Dağıtılmış Otoregresif (ARDL) model kullanılarak elde edilmektedir. Finansal gelişmeyi temsil etmek amactyla finansal gelişme literatüründe yoğun bir şekilde tercih edilen bireysel değişkenlerin aksine, bu çallşmada bu değişkenlerin çoğunu içeren bir finansal gelisme endeksi tercih edilmektedir. Calıșanın bulgulart teorik beklentilerin aksine kamu ic borcunun finansal gelismeyi pozitif etkilediğine dair kanıtlar sunmaktadır. Bu bulgular teori kapsamında değerlendirildiğinde bankaların devlet tahvili tutma yönündeki davranışlarının finansal gelişme sürecinde bir dlşlama etkisine yol açmayacă̆ ifade edilebilir. Önceki çalışmaların tersine bu bulgular kamu iç borçlarındaki artışlar ve dolayısılyla tahvil piyasasındaki derinleşmenin diğer finansal piyasaların gelişmesinde pozitif dışsallıklar ortaya çıkarmış olabileceği şeklinde yorumlanabilir.
\end{abstract}

Anahtar Kelimeler: Dışlama Etkisi, Finansal Gelişme, Kamu İç Borcu

JEL Siniflandirmast: E62, H63, O16

Abstract: Although the impact of financial development on many macroeconomic variables, particularly economic growth, has been extensively studied, empirical evidence on the determinants of financial development is very limited. This study investigates whether or not there is a significant impact of the domestic public debt on the financial development for Turkey. Estimations of the effect of public domestic borrowing on financial development for the period of 1980 to 2017 are obtained by using the Autoregressive Distributed Lag (ARDL) model. Unlike individual variables, which are highly preferred in the financial development literature in order to represent financial development, a financial development index including most of these variables is preferred in this study. The findings of the study provide evidence that domestic public debt positively affects financial development contrary to theoretical expectations. When these findings are evaluated within the scope of the theory, it can be stated that the behaviors of banks to hold government bonds will not lead to an crowding out effect in the financial development process. On the contrary to previous studies, these findings can be interpreted as the increase in domestic public debt and hence the deepening of the bond market may have caused positive externalities in the development of other financial markets.

Keywords: Crowding-out Effect, Financial Development, Domestic Public Debt JEL Classification: E62, H63, O16

\section{Giriş}

Kamu harcamalarının iktisadi büyümeyi artıracağı görüşü birçok iktisatçı tarafindan benimsenmektedir. Ancak diğer yandan kamu harcamalarındaki artışların dışlama etkisi ile iktisadi büyümeye zarar verebileceği düşüncesi de görmezden gelinmemektedir. Geleneksel görüşler dışlama etkisini artan faiz oranları sebebiyle özel sektör yatırım harcamaları, tüketim harcamaları ve kur hareketleri ile birlikte net ihracattaki azalışlarla ilişkilendirmektedir. Kamu harcamasındaki artışlar farklı kanallar aracılığıyla faiz oranlarını etkileyebilir. Bunlardan biri kamu harcamaları sonrası artan bütçe açığı ve devletin iç ve dış kaynaklardan borçlanma isteğindeki artışların yarattığı fon talebi ile birlikte oluşan faiz yükselişleridir. Bu etkileşime daha dikkatli bakıldığında devletin borçlanma ihtiyacının yoğun olarak iç borçlar ile sağlandığ1 durumlarda kamu harcamalarındaki artışların iktisadi büyüme üzerinde yaratabileceği başka olumsuz durumların ortaya çıkabildiği görülmektedir. Devletin özellikle iç borçlanmasındaki artış bankaların özel kesime verebileceği kaynakların azalmasına ve dolayısıyla tüketim ve yatırım azalışlarına yol açabilir. Bankaların özel kesime açtıkları kredilere ilişkin büyüklükler finansal gelişme literatüründe sıklıkla finansal gelişmenin göstergeleri olarak kullanılmaktadır. Finansal gelişme ve iktisadi büyüme ilişkisi hem teorik hem de ampirik olarak fazlaca sorgulanmasına

\section{Makale Geçmiși / Article History}

Başvuru Tarihi / Date of Application Kabul Tarihi / Acceptance Date

(C) 2020 Journal of Yaşar University. Published by Yaşar University. Journal of Yaşar University is an open access journal.

There is no conflict of interest or ethical concern regarding this publication.
: 17 Ocak / January 2020

: 18 Nisan / April 2020 
(King ve Levine, 1993; Levine, 1997; Rajan ve Zingales, 1998) ve bu ilişkinin büyük çoğunluk tarafından pozitif olarak değerlendirilmesine rağmen finansal gelişmeyi etkileyen değişkenlere dair bilgimiz son derece azdır. ${ }^{1}$

Son yıllarda özellikle gelişmekte olan ülkeler kamu harcamalarının finansmanında artan bir şekilde iç borçlara güvenmektedir. Kamu borcu finansmanının hızla iç borçlara doğru kayması, devletin borçlanma imkânlarını artırarak borçlanma kısıtlarından kaynaklanabilecek makroekonomik risklerin azalmasını sağlarken, aynı zamanda finansal gelişmeye yönelik endişeleri de beraberinde getirmektedir. Finansal gelişme açısından kamu borcundaki daha spesifik olarak ise kamu iç borcundaki artışlar bir yandan devletin borçlanabileceği finansal piyasaların varlığına ve gelişimine işaret ederken, diğer yandan finansal gelişmeden daha geniş beklentisi olan özel işletmelerin ve tüketicilerin finansmanı fonksiyonlarının yerine getirilmesini engelleyebilmektedir. Bu durum literatürde David Hauner (2009) tarafindan "güvenli varlıklar (safe asset)" ve "tembel bankalar (lazy banks)" şeklinde iki görüş kapsamında ele alınmaktadır. Hauner'e göre kamu iç borcundaki artışlar, bankaların güvenli kamu varlıklarını tutması sebebiyle finansal istikrara ve finansal gelişmeye pozitif katkı sağlayabilmektedir. Ancak "güvenli varlıklar görüşü (safe asset)" olarak adlandırılan bu davranış farklı sonuçlar da doğurabilmektedir. Bu sonuçlardan biri de bankaların daha güvenli olan devlet tahvillerine yönelmesinin bankaların diğer fonksiyonlarını aksatması şeklinde ortaya çıkan ve “tembel bankalar (lazy banks)” görüşü olarak adlandırılan durumdur. Bankalar kar arayışı amacıyla kredilerin yanı sıra farklı; fakat daha riskli finansal ürünler geliştirme konusunda istekli olmadıklarında bu durum bankacılık sektörünün gelişimini ve dolayısıyla finansal gelişmeyi yavaşlatabilmektedir.

Kamu iç borcu ve finansal gelişme ilişkisine dair diğer bir mantık yürütme ise yüksek enflasyon dönemlerinde banka davranışlarına ilişkin yapılabilir. Yüksek enflasyon dönemlerinde bankalar özellikle likidite avantajından dolayı krediler yerine devlet tahvillerine yönelebilirler, bu durumda yine tembel bankalar görüşü ile ilişkili olarak kamu iç borcunun finansal gelişmeyi negatif etkileyebileceği düşünülebilir. Ancak artan kamu iç borcunun finansal gelişmeyi böylesine negatif etkileyerek bir dışlama etkisi yaratmasına dair ampirik kanıtlar son derece az ve belirsizdir. Yeni oluşmaya başlayan bu literatürde yapılan ilk ampirik çalışmaların Türkiye’yi ele alması oldukça dikkat çekicidir. Türkiye yukarıda bahsedilen kavramsal çerçeveye oldukça iyi uyum sağlamaktadır. İlk olarak Türkiye gelişmekte olan bir ekonomiyi temsil etmektedir. Dolayısıyla finansal sistemin ana omurgasının bankacılık sektörü tarafından oluşturulduğu gelişmekte olan ekonomilerin finansal gelişme süreçlerini belirgin bir şekilde yansıtmaktadır. İkinci olarak Türkiye enflasyon konusunda uzun yıllardır kendi boyutundaki diğer gelişmekte olan ülkelerden negatif olarak ayrışmaktadır. Yüksek ve daha düşük istikrarlı bir enflasyonist ortamda bankaların kamu varlıklarına yönelik davranışlarının finansal gelişmeye olan katkısı merak uyandırmaktadır. Bu çalışmada temel motivasyon Türkiye için kamu iç borcu düzeyindeki değişmelerin finansal gelişme üzerindeki etkilerini ortaya çıkarabilmektir. Çalışmada zaman serisi yöntemleri tercih edilmiş olup finansal gelişme süreci 1980 ve 2017 yıllarını kapsayan uzun bir dönem için ele alınmaktadır. Zaman serisi yönteminin uygulanmış olması literatürde yer alan Ersoy’un (2012) çalışmasından, içerilen dönemin uzunluğu ve IMF tarafından oluşturulan daha kapsamlı değişkenleri içeren bir finansal gelişme endeksinin kullanılması, bireysel finansal gelişme değişkenini kullanan diğer çalışmalardan ve zaman serisi yöntemi ile Türkiye’yi inceleyen Altaylıgil ve Akkay (2013) çalışmasından farklılaşma imkanı sağlamıştır. Gecikmesi Dağıtılmış Otoregresif model kullanılarak elde edilen bulgulara göre kamu iç borcunun finansal gelişme üzerindeki etkisi diğer çalışmaların aksine pozitif olarak tespit edilmekte ve ilgili dönemde Türkiye için güvenli varlıklar görüşü desteklenmektedir.

Bu çalışmanın devamı beş bölümden oluşmaktadır. İkinci bölümde kamu iç borcu ve finansal gelişme ilişkine dair daha önce yapılan teorik ve ampirik çalışmalar özetlemektedir. Üçüncü bölümde kullanılan veriler ve yöntem tanıtılmaktadır. Dördüncü bölümde ekonometrik model tahminlerine dayanan ampirik bulgulara yer verilirken beşinci bölüm sonuç ve politika önerilerini içermektedir.

\section{Teorik ve Ampirik Literatür İncelemesi}

Kamu iç borçlarının finansal gelişme üzerinde nasıl bir etki ortaya çıkarabileceğine ilişkin tartışmalar son derece sınırlıdır. Bilindiği kadarıyla bu ilişkiyi formel olarak açıklamaya girişen ilk ve tek çalışma İsmihan ve Özkan (2012) tarafından ele alınmıştır. Bu çalışmada politika yapıcıların tercihleri, üretim arzı, borçlanma talebi, ödünç verilebilir fon arzı ve tahvil piyasalarında dengeye ilişkin teorik bir model geliştirilmektedir. Modelde maliye politikası yapıcıların tercihleri enflasyon, çıktı ve kamu harcamalarının hedeflenen değerlerinden sapmaların minimize edilmesine bağlı olarak ele alınırken para politikası ise bağımsız merkez bankası tarafından enflasyon ve çıktı açı̆̆ına bağlı olarak yürütülmektedir. Kredilere erişim ve reel ekonomik aktivite ilişkisi King ve Levine (1993) çalışmasından hareketle; özel sektör firmalarının krediye erişim olanaklarının verimliliklerini, dolayısıyla da ekonominin fonksiyonelliğini etkilediği varsayımı ile arz fonksiyonuna dahil edilmektedir. Bu doğrultuda özel sektöre verilen toplam banka kredileri ve çıktı arzı arasında verimlilik aracılığıyla bir ilişki kurulmaktadır. Modelde özel sektöre verilen toplam banka kredileri finansal gelişme göstergesi olarak kullanılmaktadır. Borçlanma talebi para ve maliye politikası kararlarının sonuçları tarafından belirlenirken kamu harcamalarının vergi gelirleri, para yaratılması ve kamu borçlanması olmak üzere üç finansman kaynağı bulunmaktadır. Devlete ve özel sektöre sağlanacak ödünç verilebilir fon arzının belirlenmesinde banka aktiviteleri için Cukierman (1991) takip edilmekte ve iyi bilinen Monti-Klein banka davranışları modelindeki gibi aksak

\footnotetext{
${ }^{1}$ Voghouei vd. (2011) çalışmasında finansal gelişmenin belirleyicilerini hukuki gelenek, kurumlar, devlet müdahalesi, dış ticaret ve dışa açıklık politikası ve politik ekonomi faktörleri olmak üzere beş temel kategoride ele almaktadır.
} 
rekabet koşullarında faaliyet gösteren bankaların pozitif bir mevduat arz eğrisi ve negatif bir kredi talep eğrisi ise karşı karşıya oldukları varsayılmaktadır. Bankaların kar fonksiyonu banka kredilerine, bankanın tuttuğu devlet tahvillerine, müşterilerin bankada tuttuğu mevduat miktarına ve bu varlık ve yükümlülüklerin likiditeleri ile ilişkili maliyetlere bağlı olarak kurulmaktadır.

Yapılan modellemeler kapsamında iki temel sonuca ulaşılmaktadır. İlk olarak kamunun ihraç ettiği tahvil miktarındaki diğer bir ifadeyle kamu sektörünün bankalardan borçlanmasındaki artış, bankaların özel sektöre borç verebilme miktarını azaltmakta, bu durum da finansal gelişmeyi olumsuz etkilemektedir. Ayrıca, finansal derinlik azaldıkça kamu sektörü borçlanmasındaki artış, özel sektörün kredi piyasalarından dışlanmasını artırmaktadır. İkinci olarak özel sektörün kredi olanaklarına erişimindeki azalma cari ve gelecek dönemde enflasyonda yükselme ve üretim düzeyinin düşmesi şeklinde ekonomi üzerinde olumsuz etkiye yol açmaktadır. Son olarak toplam banka kredilerinin büyük kısmının kamu tarafından emildiği ve devletin yurt içi tahvil piyasasında ana borçlanıcı olduğu ülkelerde, kamu borcunun finansal gelişmeye ve iktisadi aktiviteye zarar vermesi muhtemeldir. Mali genişlemenin daraltıcı etkilerinin ise finansal derinliğin ve gelişmenin daha düşük olduğu ülkelerde ortaya çıkabileceği beklenmektedir.

Meseleye ampirik olarak yaklaştığımızda ise yapılan ilk çalışmalardan biri Hauner'e (2009) aittir. Yazar daha önce bahsedildiği üzere kamu borcunun, bankaların güvenli kamu varlıklarını tutması sebebiyle finansal istikrara ve finansal gelişmeye pozitif katkı sağlayacağı "güvenli varlıklar görüşü” ancak aynı zamanda bu durumun bankacılık sektörünün gelişimini yavaşlatabileceği görüşlerine yer vermektedir. “Tembel bankalar” olarak adlandırılan ikinci görüş ise bir değer yargısı değil, bankaların rasyonel davranışlarını yansıtmaktadır. Diğer yandan 73 orta gelirli ülkenin banka verileri ile yapılan analizler sonucunda elde edilen bulgular tembel bankalar görüşünü destekler niteliktedir. Devlete bankalar tarafından daha fazla borç verilmesi bankaların karlılığını artırırken zaman içinde etkinliğini ve finansal gelişmeyi azaltmaktadır. Ancak elde edilen bulgulardan hareketle bu ilişkinin doğrusal olmayabileceği yönünde uyarılara da yer verilmektedir.

Literatürde yer alan diğer çalışmalarda ise güvenli varlıklar ve tembel bankalar görüşü gelişmiş ve gelişmekte olan ülkeler temelinde gruplandırılarak incelenmiştir. Bu gruplandırmanın karşılaştırmalı olarak ele alındığı Caballero ve Krishnamurthy (2004) tarafindan yapılana çalışmada 18 gelişmiş ve 13 gelişmekte ülke olan ülke ekonomisi için panel veri analizi yapılmıştır. Yapılan analiz sonucunda dışlama etkisinin gelişmekte olan ülkelerde gelişmiş ülkelere göre daha büyük olduğu ileri sürülmekte ve bu farkın özellikle kriz dönemlerinde oldukça yüksek seviyelere ulaştığı tespit edilmektedir. Literatür kapsamındaki diğer çalışmalar ise örneklem büyüklüğü değişmekle birlikte Caballero ve Krishnamurthy (2004) tarafından ulaşılan bulgular ile uyumluluk gösterir şekilde gelişmekte olan ülke gruplarına ilişkin analizlerden oluşmaktadır. Bu çalışmalardan en geniş ülke grubunun yer aldığı Emran ve Farazi'nin (2009) çalışmasında, 60 gelişmekte olan ülkede kamu borçlanmasının yurt içindeki bankaların sağladığı kredi miktarı üzerindeki etkisi ile dışlama etkisi araştırılmaktadır. Elde edilen sonuçlar kamu borç miktarındaki artışın özel sektöre verilen kredi miktarını azalttığı ve tembel bankalar davranışının geçerli olduğu yönündedir. 18 gelişmekte olan ülkeye ilişkin 1987-2013 arası panel verilerinin kullanıldığ İlgün (2016) tarafından yapılan çalışmada da kamu iç borcunun finansal gelişme üzerindeki etkisi uzun dönemde negatif olarak belirlenmektedir. Kamu borcunun çok yüksek olması finansal istikrarsızlığın kaynağı haline gelebilmektedir bu nedenle finansal gelişmenin sağlanabilmesi için mali disiplinin önemi vurgulanmaktadır. Gelişmiş finansal sistemin sermaye birikimi ve büyüme üzerindeki olumlu etkisi ve bu durumun maliye ve borç politikaları ile yakından ilişkili olduğunu belirten Kumhof ve Tanner'in (2005) çalışmasında da gelişmekte olan ülkelerde kurumsal ve yasal altyapının zayıf olduğu kabulünden hareket edilmiştir. Bu durumun da gelişmekte olan ülkelerde istikrarlı borç yönetimi ile banka bazlı finansal aracılığı kolaylaştırabileceği belirtilerek, finansal gelişme sürecinde kamu borcunun finansal sistemdeki güvenli varlık işlevine vurgu yapılmaktadır.

Diğer taraftan Janda ve Kravtsov (2017) tarafından yapılan çalışmada kamu iç borcu ile finansal gelişme arasındaki ilişki, örneklemin kapsamı gelişmekte olan ülkeler dışına çıkarılarak, 1995-2014 dönemi için 26 adet Merkez Avrupa, Balkan ve Baltık ülkesi için incelenmiştir. Her ne kadar gelişmiş ülke gruplarına ilişkin olsa da bu çalışma kapsamında elde edilen sonuçlar gelişmekte olan ülkelere ilişkin yapılan çalışmalarda elde edilen sonuçlar ile benzerlik göstermektedir. Buna göre yapılan inceleme sonucunda Avrupa Birliği ülkelerinin tamamı için geçerli olmamakla birlikte ülke grupları bazında kamu iç borcundaki büyümenin kısa vadede bankacılık sektörünün etkinliği üzerinde pozitif etkisi bulunurken, kısa-orta ve uzun vadede özel sektöre verilen krediler üzerinde negatif etkiye sahip olduğu sonucuna ulaşılmıştır. Ayrıca sadece Merkez Avrupa ülkelerinde dışlama etkisinin ortaya çıktığ tespit edilmiştir. Bununla birlikte 1980-2012 dönemi için 13 gelişmiş ülkenin incelendiği Afonso ve Jalles (2017) tarafından yapılan çalışmada ise, kısa vadeli kamu borçlanmasının mali sürdürülebilirlik üzerinde negatif etkisi bulunurken, uzun vadeli borçlanmanın pozitif etkiye sahip olduğu şeklinde diğer ülke gruplarına ilişkin yapılan çalışmalardan farklı bir sonuca ulaşılmıştır. Gelişmekte olan ve gelişmiş ülke grupları bazında yapılan bütün bu çalışmalardan farklı olarak Kutivadze (2011) tarafindan 130 ülkeye ait 1990-2007 arası verilerin kullanıldığı çalışmada ise kamu borcu ile finansal gelişme arasında pozitif bir ilişki tespit edilmektedir. Ayrıca bu ilişki, ülkeler gelir düzeylerine göre farklı gruplara ayrıldığında da geçerlilik göstermektedir.

Gelişmekte olan ülkelerin gruplandırılarak incelendiği çalışmalardan farklı olarak tek ülke örnekleminden oluşan çalışmalar da bulunmaktadır. Bu çalışmalardan Mun ve İsmail (2015) tarafından kamu iç borcu ve finansal gelişme ilişskisi Malezya örnekleminde 1980 ve 2010 dönemi için sorgulamaktadır. Malezya örneklemi için ARDL yöntemi kullanılarak ulaşılan bulgular, gelişmekte olan ülke gruplarının incelendiği çalışmaların bulguları ile uyumlu olup, bankalardaki kamu iç borcunun finansal gelişmeyi negatif etkilediği şeklindedir. Ayrıca gelişmiş ve gelişmekte olan ülke gruplarının karşılaştırmalı olarak ele alındığı Caballero ve Krishnamurthy (2004) tarafından gelişmekte olan ülkeler için ulaşılan, 
dışlama etkisinin finansal krizler sırasında daha belirgin hale geldiği tespitinin, Malezya örneklemi için de geçerli olduğu sonucuna ulaşılmıştır. Sınırlı sayıda olmakla birlikte Türkiye örneklemine ilişkin çalışmalar da bulunmaktadır. Veri setleri farklılık göstermekle birlikte Ersoy (2012) ve Altaylıgil ve Akkay (2013) tarafından yapılan çalışmalarda benzer bulgular elde edilmiştir. İlk olarak Ersoy’un (2012) çalışması ele alındığında 1973-2007 yıllarını kapsayan Türkiye verileri ve Türkiye'deki 28 ticari bankanın 2002-2008 yıllarına ait panel veri kullanılarak farklı testler yapıldı̆̆ görülmektedir. Öncelikle uzun dönemli ilişkiyi tespit edebilmek için yapılan sınır testine göre bankaların kamu borcu portföylerinin finansal gelişmeyi negatif etkilediği sonucuna varılmaktadır. İlgili değişkenler arasındaki nedensellik ilişkisini tespit edebilmek amacıyla yapılan Granger nedensellik testi ise yalnızca kamu iç borcundan finansal gelişmeye doğru tek yönlü bir nedensellik olduğunu göstermektedir. Ayrıca maliyet etkinsizliği, kamu borcu portföylerinin uzun dönemde bankacılık sistemi ve finansal gelişmeyi etkilediği kanallardan biri olarak tespit edilmektedir. Altaylıgil ve Akkay (2013) tarafından yapılan çalışmada ise kamu borcu ve finansal gelişme ilişkisi 2002 ve 2012 arası dönemde Türkiye ekonomisi için araştırılmaktadır. Çeyreklik verilere ve farklı finansal gelişme göstergelerine dayanan zaman serisi analizine göre Ersoy (2012) tarafından ulaşılan bulgular ile benzer şekilde, kamu iç borcundaki artışların finansal gelişmeyi negatif etkileyeceği sonucuna varılmaktadır. Her iki çalışmada da ilgili yazarlar tarafından her ülkenin kendine özgü finansal ve ekonomik koşulları nedeniyle kamu iç borcundaki değişikliklere karşı farklı tepkiler vereceği; sonuçların genelleştirilmemesi gerektiği vurgulanarak, maliye politikalarının ülkeye özgü olması ve daha itinalı bir şekilde tasarlanmasını önerilmektedir. Türkiye'ye ilişkin bu iki çalışmadan farklı olarak Yılmaz (2017) tarafından yapılan çalışmada ise farklılık gösterebilecek bulgulara ulaşılmıştır. Türkiye'de kamu iç borcunun mevduat bankalarının özel kesim kredilerini nasıl etkilediğini tespit etmeyi amaçlayan çalışmada 2002:1-2016:4 dönem verileri ve VAR ve yapısal VAR yöntemi ile yapılan analizde devlet borçlanma senetlerindeki artışın kısa dönemde özel kesim kredilerini dışladığına dair kanıtlar elde edilmektedir. Ulaşılan bu sonuçlar literatürdeki diğer çalışmaların sonuçları benzerlik gösterse de, bu çalışmalardan farklı olarak devlet borçlanma senetlerindeki artışın orta uzun vadede özel kesim kredilerini arttırdığı sonucuna ulaşılmıştır.

\section{Veri Seti ve Yöntem}

Türkiye’de 1980-2017 döneminde kamu iç borcunun finansal gelişme üzerindeki etkisini tespit etmek amacıyla tahmin edilen ampirik modelin formu aşağıdaki gibidir:

$$
f d_{t}=\alpha_{0}+\alpha_{1} p d_{t}+\alpha_{2} g r_{t}+\alpha_{3} i n f_{t}+\alpha_{4} s_{t}+\alpha_{5} t r_{t}+u_{t}
$$

Bağımlı değişken olarak kullanılan $f d$, finansal gelişme endeksini simgelemektedir. pd değişkeni kamu iç borcunun GSYİH (sabit fiyatlarla) içindeki yüzde payını, gr değişkeni kişi başına GSYİH büyüme oranını, inf değişkeni enflasyon oranını, $s$ değişkeni yurt içi tasarruf oranının GSYİH içindeki yüzde payını ve son olarak tr değişkeni ise ticarette dişa açıklığı temsil etmektedir. Analizde kullanılan açıklayıcı değişkenler finansal gelişme üzerindeki etkileri daha önceki çalışmalarda sıklıkla belirlenen değişkenlerden seçilmektedir.

IMF, ülkelerin finansal sistemleri çeşitli olduğundan finansal sisteme ilişkin birden fazla göstergeye bakılarak finansal gelişmeye dair tek bir endeksin oluşturulması gerektiğini vurgulamaktadır. Bu nedenle endeks oluşturulurken ilk olarak finansal kurum ve finansal piyasaların derinlikleri, erişilebilirlikleri ve etkinliği açısından gelişmişliklerini gösteren alt indeksler oluşturulmaktadır. Finansal kurumlar bankaları, sigorta şirketlerini, yatırım ve emeklilik fonlarını içerirken; finansal piyasalar hisse senedi ve tahvil piyasasını içermektedir. Finansal gelişme endeksi, piyasaların büyüklüğü ve likiditesini gösteren derinlik, bireylerin ve şirketlerin finansal hizmetlere erişim yeteneğini ima eden erişim ve son olarak kurumların düşük maliyetle ve sürdürülebilir gelirlerle finansal hizmetler sunma yeteneği ile sermaye piyasalarının faaliyet düzeyini gösteren etkinlik faktörlerinin bir kombinasyonu olarak oluşturulmaktadır (Svirydzenka, 2016: 4-5). Denklem 1'in tahmini hem finansal gelişme endeksi hem de bu endeksi oluşturan alt indeksler için yapılmaktadır. Bu endekslerden $f i$ ve $f m$ sirasiyla finansal kurumlar ve finansal piyasaları temsil etmektedir. Her iki endeksin de yukarıda belirtildiği gibi üç temel alt indeksi bulunmaktadır. fid finansal kurumlar derinlik endeksi, fia finansal kurumlar erişim endeksi ve fie ise finansal kurumlar etkinlik endeksini temsil etmektedir. Finansal piyasalara ait alt endeksler ise; $f m d$ finansal piyasalar derinlik endeksi, fma finansal piyasalar erişim endeksi ve fme finansal piyasalar etkinlik endeksi şeklindedir. Finansal gelişme endeksi ve alt endekslere ait veriler IMF veri tabanından, yurt içi tasarruf oranı ve kamu iç borcuna ait veriler Merkez Bankası veri tabanından elde edilirken diğer açıklayıcı değişkenlerin tümü Dünya Bankası veri tabanından elde edilmektedir ayrıca ilgili değişkenlere ait tanımlayıcı istatistikler Tablo 1'de verilmektedir.

Tablo 1. Değişkenlere Ait Tanımlayıcı İstatistikler

\begin{tabular}{|c|c|c|c|c|c|c|}
\hline 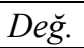 & Ort. & Medyan & Maks. & Min. & Std. Hata & Gözlem \\
\hline$f d$ & 0.337967 & 0.367725 & 0.519036 & 0.125864 & 0.135163 & 38 \\
\hline$f i$ & 0.289433 & 0.250204 & 0.480921 & 0.155637 & 0.100520 & 38 \\
\hline $\mathrm{fm}$ & 0.379270 & 0.487557 & 0.580990 & 0.084485 & 0.193415 & 38 \\
\hline fid & 0.099772 & 0.077612 & 0.205195 & 0.048442 & 0.045250 & 38 \\
\hline fia & 0.317020 & 0.259815 & 0.581988 & 0.168238 & 0.123350 & 38 \\
\hline fie & 0.425881 & 0.413799 & 0.613073 & 0.107764 & 0.135359 & 38 \\
\hline fmd & 0.177572 & 0.202086 & 0.365846 & 0.012983 & 0.127893 & 38 \\
\hline
\end{tabular}


Sekmen, T., Doğan, E., Topuz, S. G. / Journal of Yasar University, 2020, 15/59, 544-559

\begin{tabular}{|l|l|l|l|l|l|l|}
\hline$f m a$ & 0.333850 & 0.341056 & 0.471902 & 0.175732 & 0.086104 & 38 \\
\hline$f m e$ & 0.673287 & 1.000000 & 1.000000 & 0.074681 & 0.411007 & 38 \\
\hline$p d$ & 0.126201 & 0.024882 & 0.330271 & $2.34 \mathrm{E}-06$ & 0.138776 & 38 \\
\hline$g r$ & 0.028780 & 0.039424 & 0.094238 & -0.07357 & 0.042837 & 38 \\
\hline$s$ & 0.241273 & 0.237483 & 0.384500 & 0.169794 & 0.045375 & 38 \\
\hline inf & 0.410066 & 0.382353 & 1.052150 & 0.062510 & 0.307544 & 38 \\
\hline$t r$ & 0.411442 & 0.448399 & 0.549703 & 0.170898 & 0.096583 & 38 \\
\hline
\end{tabular}

Tahmin edilen ampirik modelde finansal gelişmenin temel belirleyicileri olarak literatürde sıklıkla kullanılan değişkenlere başvurulmaktadır. İlk olarak ekonomik büyümenin finansal kalkınma sürecinde önemli bir rol oynadığ Robinson (1952) ve Patrick (1966) tarafından vurgulanmaktadır. Robinson (1952) üretim arttıkça finansal hizmete olan talebin de arttığını bu nedenle de ekonomik büyümenin finansal gelişme üzerinde pozitif etkisinin olduğunu savunmaktadır. Patrick (1966) ise iki değişken arasındaki ilişkinin talep çekişli ve arz itişli olarak tanımladığ 1 iki farklı şekilde olabileceğini açıklamaktadır. Talep çekişli tarafta ekonomik büyüme arttıkça finansal hizmetlere olan talebin artacağı böylece finansal sistemin gelişmesini sağlayacağı vurgulanırken; arz itişli tarafta ise finansal kurum ve araçlardaki iyileşmenin yatırımlar aracılığıyla ekonomik büyümeyi teşvik edeceği ileri sürülmektedir. Bu iki kanalın geçerli olması durumunda finansal gelişme ile ekonomik büyüme arasındaki ilişkinin çift yönlü olabileceği vurgulanmaktadır. Arz itişli tarafta gerçekleşen finansal gelişmenin tasarrufları ve yatırımları arttırarak ekonomik büyümeye neden olması döngü içerisinde yer alan tasarruf oranlarının da finansal gelişme üzerinde belirleyici olduğuna işaret etmektedir. Bunun yanı sıra modelde finansal gelişmenin diğer belirleyicisi olarak dışa açıklık kullanılmaktadır. Literatürde artan diş ticaret hacminin finans sektörünü geliştirebileceği belirtilmektedir. Beck (2002) gelişmiş finansal sisteme sahip ekonomilerin imalat sanayilerinde karşılaştırmalı bir avantaja sahip olduklarını ve bu alanda ihracatçı olduklarını belirtir. Diğer yandan ilișkinin ters yönlü de geçerli olduğunu savunan Do ve Levchenko (2004), ülkenin finansal gelişiminin içsel bir değişken olduğunu ve ticaretin finansal gelişme üzerinde belirleyici olduğunu vurgulamaktadır. Benzer şekilde Rajan ve Zingales (2003) ticaret açıklığının, yurt dışına sermaye akışı serbest olduğunda rekabeti arttırarak finansal gelişmeyi teşvik ettiğini ileri sürülmektedir. Finansal gelişmenin belirleyicilerinden bir diğeri olarak kullanılan enflasyonun ise finansal gelişmeyi negatif etkilediği Huybens ve Smith (1999) tarafından belirtilmektedir. Enflasyonun yüksek olduğu ülkelerde para ve varlıkların reel getirileri azalmaktadır. Bunun yanı sıra göreli orta düzeydeki enflasyon oranlarında enflasyon ile bankaların özel sektöre borç verme hacmi; ihraç edilen banka borç miktarı ve hisse senedi piyasalarında işlem hacmi arasında güçlü bir negatif ilişki olduğu öngörülmektedir. Ancak enflasyonun daha yüksek seviyelerinde ise bu ilişki ortadan kalkabilmektedir (Boyd vd. 2001: 224). Yüksek enflasyon aynı zamanda uzun vadeli finansal sözleşmeleri de engelleyecek ve finansal aracılar ellerindeki likit portföyleri koruma eğiliminde olacaktır. Bu nedenle enflasyonist ortamlarda aracı kurumlar uzun vadeli finansman sağlamaya daha az istekli olacaktır (Rousseau ve Wachtel, 2001: 4).

Kamu borcunun finansal gelişme üzerindeki etkisini tespit etmek amacıyla, öncelikle söz konusu değişkenler arasında uzun dönemli bir ilişkinin bulunup bulunmadığının tespitine yönelik eşbütünleşme ilişkisi araştırılmaktadır. Değişkenlerin aynı düzeyde bütünleşik olması durumunda Engle ve Granger (1987), Johansen (1988) tarafindan geliştirilen klasik eşbütünleşme testleri uygulanabilmektedir. Serilerin farklı derecelerden bütünleşik olması durumunda ise bu testlerin kullanılması önerilmemektedir. Bu anlamda Pesaran vd. (2001) tarafından geliştirilen ARDL sınır testi yaklaşımı farklı derecelerden bütünleşik seriler arasındaki ilişkinin incelenmesine imkan vererek modelleme aşamasında önemli bir esneklik sağlamaktadır. Bu çalışmada birim kök testleri sonucunda elde edilen bulgulara dayanarak ARDL sınır testi yaklaşımı kullanılmaktadır. En küçük kareler yöntemine dayanan bu yaklaşım, birim kök testi uygulaması gerektirmeksizin, durağanlık düzeyleri I(1) ya da I(0) olan değişkenler ile eşbütünleşme testi yapılabilmesine ve anlamlı sonuçlar elde edilebilmesine imkân tanımaktadır (Pesaran ve Pesaran 1997). Ancak yöntemde serilerin I(2) olmaması gerektiği önerildiğinden seriler birim kök testlerine tabi tutulmaktadır. ARDL modelinin uzun dönem formu aşağıda gibi oluşturulmaktadır:

$$
\begin{gathered}
\Delta f d_{t}=\alpha_{0}+\sum_{i=1}^{j} \alpha_{1 i} \Delta f d_{t-i}+\sum_{i=0}^{k} \alpha_{2 i} \Delta p d_{t-i}+\sum_{i=0}^{l} \alpha_{3 i} \Delta g r_{t-i}+\sum_{i=0}^{m} \alpha_{4 i} \Delta i n f_{t-i}+\sum_{i=0}^{n} \alpha_{5 i} \Delta s_{t-i}+\sum_{i=0}^{0} \alpha_{6 i} \Delta t r_{t-i} \\
+\beta_{0} f d_{t-1}+\beta_{1} p d_{t-1}+\beta_{2} g r_{t-1}+\beta_{3} i n f_{t-1}+\beta_{4} s_{t-1}+\beta_{5} t r_{t-1}+u_{t}
\end{gathered}
$$

Denklem 2 de $\alpha_{0}$ sabit terimi, $u_{t}$ hata terimini $\Delta$ simgesi ise değişkenlerin farkını temsil etmektedir. Model için en uygun gecikme uzunluğunun saptanmasından sonra en küçük kareler tahmin yöntemi ile tahmin edilen modelde $H_{0}=$ $\beta_{0}=\beta_{1}=\beta_{2}=\beta_{3}=\beta_{4}=\beta_{5}=0$ şeklindeki "eşbütünleşme yoktur" boş hipotezi Wald testi ve F istatistiği ile sınanmaktadır. Buna göre $\mathrm{F}$ istatistiğinin alt sınırdan küçük olması durumunda boş hipotez reddedilemezken, $\mathrm{F}$ istatistiğinin üst sınırdan büyük olması durumunda boş hipotez reddedilerek, değişkenler arasında eşbütünleşme ilişkisinin bulunduğu sonucuna varılabilmektedir. Eşbütünleşme ilişkisinin olduğunun tespit edilmesi ve modelin uygunluğuna yönelik tanı testlerinin tutarlılığı sonrasında değişkenler arasındaki uzun dönemli ilişkinin varlığı ortaya konulmaktadır. Bunun yanı sıra kısa dönemli dengesizliğin ne kadarının uzun dönemde değişeceğini gösteren hata düzeltme teriminin yer aldığı hata düzeltme modeli ise aşağıdaki gibi oluşturulmaktadır: 


$$
\begin{gathered}
\Delta f d_{t}=\varphi_{0}+\sum_{i=1}^{r} \varphi_{1 i} \Delta f d_{t-i}+\sum_{i=0}^{s} \varphi_{2 i} \Delta p d_{t-i}+\sum_{i=0}^{t} \varphi_{3 i} \Delta g r_{t-i} \sum_{i=0}^{u} \varphi_{4 i} \Delta i n f_{t-i}+\sum_{i=0}^{v} \varphi_{5 i} \Delta s_{t-i}+\sum_{i=0}^{y} \varphi_{6 i} \Delta t r_{t-i} \\
+\mu E C T_{t-1}+u_{t}
\end{gathered}
$$

Denklem 3'de yer alan $\mu$ hata düzeltme katsayısını göstermektedir; negatif ve istatistiki olarak anlamlı tahmin edilen $\mu$ katsayısı kısa dönemdeki şokların uzun dönemdeki ayarlanma hızının yorumlanmasına imkan sağlamaktadır.

\section{Ampirik Sonuçlar}

Çalışmada kamu iç borcu ve finansal gelişme arasındaki ilişsiyi incelemek amacıyla kullanılan ARDL modelinin uygunluğu için öncelikle serilerin birim kök sınaması yapılmaktadır. Değişkenlerin durağanlık seviyeleri Dickey ve Fuller (DF) testine dayalı ADF ve PP (Phillips-Perron) birim kök testleri kullanılarak incelenmektedir. Her iki test sonucuna ilişkin bilgiler Tablo 2'de verilmektedir. Sonuçlar incelendiğinde finansal piyasalar derinlik endeksi, ekonomik büyüme ve ticaret açıklığı değişkenleri hariç diğer tüm değişkenlerin birinci farkında durağan oldukları görülmektedir. Bu değişkenlerin ise her iki test sonucuna göre de düzeyde durağan oldukları tespit edilmektedir. Birim kök testlerinden elde edilen bu sonuçlar çalışmanın temelini oluşturan kamu borcunun finansal gelişme endeksi üzerindeki uzun dönemli etkisinin ARDL (Gecikmesi Dağıtılmış Otoregresif Model) yöntemi ile sınanabileceğinin uygun olduğunu ifade etmektedir.

Analizin ikinci aşamasında değişkenler arasında uzun dönemli ilişkinin olup olmadığını tespit edebilmek için ARDL sınır testi yaklaşımı değerlendirilmektedir. Tablo 3 incelendiğinde tüm modeller için ARDL sınır testinden elde edilen F istatistiğine ilişkin değerlerin üst sınır değerlerinden büyük olduğu görülmektedir. Bu bulgular değiş̧kenler arasında eşbütünleşme ilişkisinin varlığına dair kanıt sunmaktadır. Değişkenler arasında uzun dönemli bir ilişkinin varlığı tespit edildikten sonra model değişkenlerine ilişkin uzun dönemli katsayı tahminleri incelenerek çıkarım yapılabilmektedir.

Tablo 2. Birim Kök Test Sonuçları

\begin{tabular}{|c|c|c|c|c|c|c|c|c|}
\hline & \multicolumn{4}{|c|}{ Düzey } & \multicolumn{4}{|c|}{ Birinci Fark } \\
\hline & \multicolumn{2}{|c|}{$A D F$} & \multicolumn{2}{|c|}{ Phillips-Perron } & \multicolumn{2}{|c|}{$A D F$} & \multicolumn{2}{|c|}{ Phillips-Perron } \\
\hline 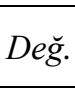 & Sabitli & $\begin{array}{l}\text { Sabit ve } \\
\text { Trend }\end{array}$ & Sabitli & $\begin{array}{l}\text { Sabit ve } \\
\text { Trend }\end{array}$ & Sabitli & $\begin{array}{l}\text { Sabit ve } \\
\text { Trend }\end{array}$ & Sabitli & $\begin{array}{l}\text { Sabit ve } \\
\text { Trend }\end{array}$ \\
\hline$f d$ & -0.96 & -2.59 & -0.88 & -2.58 & $-7.10^{* * *}$ & $-7.00 * * *$ & $-7.19 * * *$ & $-7.08^{* * *}$ \\
\hline$f i$ & -0.39 & -1.72 & -0.32 & 1.68 & $-6.64 * * *$ & $-6.72 * * *$ & $-6.64 * * *$ & $-6.94 * * *$ \\
\hline$f m$ & -1.30 & -1.25 & -1.30 & -1.25 & $-6.20 * * *$ & $-6.24 * * *$ & $-6.20 * * *$ & $-6.23 * * *$ \\
\hline fid & 1.44 & -0.51 & 2.58 & -0.06 & $-5.81 * * *$ & $-6.03 * * *$ & $-5.81 * * *$ & $-9.00^{* * *}$ \\
\hline fia & 0.13 & -1.57 & 0.48 & -0.90 & $-4.27 * * *$ & $-4.44 * * *$ & $-4.29 * * *$ & $-4.32 * * *$ \\
\hline fie & -1.84 & -2.77 & -1.79 & -2.84 & $-7.72 * * *$ & $-7.63 * * *$ & $-7.72 * * *$ & $-7.63 * * *$ \\
\hline fmd & -1.30 & $-3.84 * *$ & -0.94 & $-3.80 * *$ & $-6.55^{* * *}$ & $-6.46 * * *$ & $-12.2^{* * *}$ & $-12.6 * * *$ \\
\hline fma & -1.96 & -1.38 & -1.97 & -1.43 & $-5.42 * * *$ & $-5.49 * * *$ & $-5.40^{* * *}$ & $-5.48^{* * *}$ \\
\hline fme & -1.40 & -1.85 & -1.31 & -1.67 & -7.87 & $-7.86^{* * *}$ & $-7.71 * * *$ & $-7.77 * * *$ \\
\hline$p d$ & -0.06 & -2.04 & $\begin{array}{l}-0.28 \\
\end{array}$ & -1.90 & $-4.40 * * *$ & $-4.38 * * *$ & $-4.37 * * *$ & $-4.35 * * *$ \\
\hline$g r$ & $-0.63 * * *$ & $-6.64 * * *$ & $-6.69 * * *$ & $-7.30 * * *$ & $-10.4^{* * * *}$ & $-10.2^{2 * * *}$ & $-22.1^{* * *}$ & $-21.5^{* * *}$ \\
\hline$s$ & -2.40 & -2.34 & -2.24 & -2.25 & $-8.05^{* * *}$ & $-8.09 * * *$ & $-8.13^{* * * *}$ & $-8.09 * * *$ \\
\hline inf & -1.86 & -1.97 & -1.94 & -2.12 & $-7.12 * * *$ & $-7.02 * * *$ & $-7.42^{* * *}$ & $-7.13^{* * *}$ \\
\hline $\operatorname{tr}$ & -2.37 & $-3.66 * *$ & -2.37 & $-3.50 *$ & $-5.65 * * *$ & $-5.58 * * *$ & $-7.24 * * *$ & $-8.06 * * *$ \\
\hline
\end{tabular}

Not: ADF testinde sabitli ve sabitli-trendli t-istatistik değerleri verilmiş, gecikme uzunluğu Schwarz bilgi kriterine göre belirlenmiş̧ir. Phillips-Perron test sonuçları test istatistik değerleridir. Optimal gecikme uzunluğu Bartlett kernel (default) spectral estimation yöntemi ve Newey-West Bandwidth (automatic selection) kriteri kullanılarak belirlenmiştir. ***, **, * sirasıyla \%1, \%5 ve \%10 düzeyinde istatistiksel olarak anlamlılığı göstermektedir. Sabitli modelde test kritik değerleri $\% 1, \% 5$ ve $\% 10$ anlam düzeyi için sırasıyla $-3.62,-2.94$ ve 2.61 iken sabit ve trendli modelde sırasıyla -4.22 , -3.53 ve 3.20'dir.

Tablo 3. ARDL Sınır Test Sonuçları

\begin{tabular}{|l|c|c|}
\hline Bă̆ıml Değişken & ARDL Model & F-istatistiği \\
\hline fd & ARDL $(1,2,3,4,2,4)$ & $18.86^{* * *}$ \\
\hline fi & ARDL $(1,4,4,2,2,3)$ & $15.24^{* * *}$ \\
\hline fm & ARDL $(1,4,3,4,4,4)$ & $10.00^{* * *}$ \\
\hline fid & ARDL $(3,4,2,4,4,0)$ & $4.90^{* *}$ \\
\hline fia & ARDL $(2,4,0,0,4,4)$ & $4.97^{* * *}$ \\
\hline
\end{tabular}




\begin{tabular}{|c|c|c|c|}
\hline fie & $\operatorname{ARDL}(1,1,3,1,3,2)$ & \multicolumn{2}{|c|}{$6.96 * * *$} \\
\hline fmd & $A R D L(1,0,1,3,0,3)$ & \multicolumn{2}{|c|}{$5.78 * * *$} \\
\hline fma & $\operatorname{ARDL}(3,1,3,3,3,2)$ & \multicolumn{2}{|c|}{$6.34 * * *$} \\
\hline fme & $A R D L(3,4,4,4,3,4)$ & \multicolumn{2}{|c|}{$8.84 * * *$} \\
\hline \multicolumn{4}{|c|}{ Sinır Kritik Değerleri } \\
\hline Model & Asimptotik Kritik Değgeri & Alt Sinır, I(0) & Üst Sinır, I(1) \\
\hline \multirow{3}{*}{ Sabit } & $\% 10$ & 2.26 & 3.35 \\
\hline & $\% 5$ & 2.62 & 3.79 \\
\hline & $\% 1$ & 3.41 & 4.68 \\
\hline \multirow{3}{*}{ Sabit ve Trend } & $\% 10$ & 2.75 & 3.79 \\
\hline & $\% 5$ & 3.12 & 4.25 \\
\hline & $\% 1$ & 3.93 & 5.23 \\
\hline
\end{tabular}

Not: $* * *, * *, *$ sırasıyla $\% 1, \% 5$ ve $\% 10$ düzeyinde istatistiksel olarak anlamlılı̆̆1 göstermektedir. Parantez içindeki değerler tahmin edilen modeldeki değişkenlerin uygun gecikme uzunluğunu temsil etmektedir.

Tablo 4 açıklayıcı değişkenlerin uzun dönem katsayılarına ilişkin tahminleri göstermektedir. İlk olarak tahmin edilen modellerin uygunluğu için yapılan testlerin sonuçları incelendiğinde; Breusch-Godfrey LM testi modelde otokorelasyon, Breusch-Pagan-Godfrey (BPG) testi ise değişen varyans sorununun olmadı̆̆ını göstermektedir. Ayrıca bağımlı değişkenin finansal kurumlar derinlik endeksi olduğu model hariç diğer tüm modellerde Ramsey-Reset testine göre kurulan modelin fonksiyonel formunun tutarlı olduğu ve dolayısıyla elde edilen tahminlere güvenilebileceği sonucuna varılmaktadır.

Kamu iç borcuna ilişkin değişkenin katsayısı ise kamu iç borcunun uzun dönemde finansal gelişme üzerinde pozitif bir etkiye sahip olduğuna dair istatistiksel olarak anlamlı kanıtlar sunmaktadır. Bu kanıtlar hem temel finansal gelişme endeksi hem de alt endeksleri için de desteklenmektedir. Kamu iç borcunun finansal gelişmenin alt endeksleri üzerinde etkisinin anlamlı olduğu tüm modellerde katsayı pozitiftir. Kamu iç borcunun temel finansal gelişme endeksi üzerindeki etkisi \%1 düzeyinde anlamlı iken diğer alt endeksi üzerindeki etkisinin anlam düzeyinin farklılaştığı söylenebilir. Kamu iç borcunun bu bağımlı değişkenlerden; finansal kurumlar ve finansal piyasalar alt endeksi üzerindeki etkisi \%10, finansal kurumlar erişim ve finansal kurumlar etkinlik endeksi üzerindeki etkisi \%5 düzeyinde anlamlıdır. Bu bulgular İsmihan ve Özkan (2012) modelinin çıkarımlarını, Hauner (2009)'in tembel bankalar görüşünü, Emran ve Farazi (2009), Ersoy (2012), Altaylıgil ve Akkay (2013) ve İlgün (2016) çalışmalarının bulgularını desteklemezken; Kutivadze (2011)'nin sonuçları ve Yılmaz'ın (2017) orta uzun vade sonuçları ile paraleldir.

Tablo 4. Uzun Dönem Katsayı Tahminleri

\begin{tabular}{|c|c|c|c|c|}
\hline & \multicolumn{4}{|c|}{ Bağımlı Değişkenler } \\
\hline $\begin{array}{l}\text { Bağımsız } \\
\text { Değişkenler }\end{array}$ & $f d$ & fi & $f m$ & fid \\
\hline$p d$ & $\begin{array}{r}0.624^{* * *} \\
(0.183) \\
\end{array}$ & $\begin{array}{l}\text { 2.143* } \\
(1.056) \\
\end{array}$ & $\begin{array}{l}1.491 * \\
(0.691) \\
\end{array}$ & $\begin{array}{r}-0.134 \\
(0.359) \\
\end{array}$ \\
\hline$g r$ & $\begin{array}{r}-0.489 * * \\
(0.174)\end{array}$ & $\begin{array}{r}-0.306 \\
(0.773)\end{array}$ & $\begin{array}{r}-1.247 * * \\
(0.440)\end{array}$ & $\begin{array}{r}-1.030 \\
(0.586)\end{array}$ \\
\hline$S$ & $\begin{array}{r}-0.462 * * * \\
(0.111) \\
\end{array}$ & $\begin{array}{r}1.147^{* *} \\
(0.449)\end{array}$ & $\begin{array}{c}-0.912 * \\
(0.444) \\
\end{array}$ & $\begin{array}{r}1.029 * * \\
(0.390) \\
\end{array}$ \\
\hline $\inf$ & $\begin{array}{r}0.112 * \\
(0.062)\end{array}$ & $\begin{array}{r}0.653 * * \\
(0.226)\end{array}$ & $\begin{array}{r}0.376 \\
(0.220)\end{array}$ & $\begin{array}{r}0.107 \\
(0.125)\end{array}$ \\
\hline $\operatorname{tr}$ & $\begin{array}{r}0.064149 \\
(0.163) \\
\end{array}$ & $\begin{array}{r}-2.529 * * * \\
(0.676) \\
\end{array}$ & $\begin{array}{r}1.235^{* *} \\
(0.360)\end{array}$ & $\begin{array}{r}-0.024 \\
(0.113) \\
\end{array}$ \\
\hline$C$ & $\begin{array}{r}0.226 * * * \\
(0.041) \\
\end{array}$ & $\begin{array}{r}0.429 * * \\
(0.157) \\
\end{array}$ & $\begin{array}{r}-0.054 \\
(0.141)\end{array}$ & $\begin{array}{c}-0.293^{*} \\
(0.145)\end{array}$ \\
\hline Trend & $\begin{array}{r}0.005^{* * *} \\
(0.000)\end{array}$ & $\begin{array}{l}0.011^{*} \\
(0.005)\end{array}$ & $\begin{array}{l}-0.007 * \\
(0.003)\end{array}$ & $\begin{array}{r}0.007 * * * \\
(0.002)\end{array}$ \\
\hline Model Tanı Testleri & \multicolumn{4}{|c|}{ Test Istatistikleri } \\
\hline Breusch-Godfrey LM testi & $\begin{array}{l}0.800 \\
(0.478)\end{array}$ & $\begin{array}{l}3.927 \\
(0.059)\end{array}$ & $\begin{array}{l}2.853 \\
(0.149)\end{array}$ & $\begin{array}{l}2.737 \\
(0.124)\end{array}$ \\
\hline Değişen Varyans testi: BPG & $\begin{array}{l}1.353 \\
(0.308) \\
\end{array}$ & $\begin{array}{l}0.589 \\
(0.859) \\
\end{array}$ & $\begin{array}{l}0.586 \\
(0.848) \\
\end{array}$ & $\begin{array}{l}0.593 \\
(0.855) \\
\end{array}$ \\
\hline$J-B$ Normality test & $\begin{array}{l}1.132 \\
(0.567)\end{array}$ & $\begin{array}{l}2.883 \\
(0.236)\end{array}$ & $\begin{array}{l}2.855 \\
(0.239) \\
\end{array}$ & $\begin{array}{l}16.309 \\
(0.000) \\
\end{array}$ \\
\hline Ramsey-Reset testi & $\begin{array}{l}1.121 \\
(0.288)\end{array}$ & $\begin{array}{l}1.511 \\
(0.161)\end{array}$ & $\begin{array}{l}1.561 \\
(0.169)\end{array}$ & $\begin{array}{l}2.410 \\
(0.039)\end{array}$ \\
\hline
\end{tabular}


Not: Uygun model seçimi Akaike bilgi kriterine göre yapılmaktadır. Katsayılara ait standart hatalar parantez içerisinde yer almakta ve $* * *, * *, *$ sırasıyla $\% 1, \% 5$ ve $\% 10$ düzeyinde istatistiksel olarak anlamlılığı göstermektedir. Model tanı testlerinin olasılık değerleri parantez içerisinde gösterilmektedir.

Tablo 5. Uzun Dönem Katsayı Tahminleri (Devam)

\begin{tabular}{|c|c|c|c|c|c|}
\hline & \multicolumn{5}{|c|}{ Bağımlı Değişkenler } \\
\hline $\begin{array}{l}\text { Bă̆ı̆ısız } \\
\text { Değişkenler }\end{array}$ & fia & fie & fmd & fma & fme \\
\hline$p d$ & $\begin{array}{r}2.275^{* *} \\
(0.814) \\
\end{array}$ & $\begin{array}{r}2.821 * * \\
(1.095) \\
\end{array}$ & $\begin{array}{r}0.052 \\
(0.325) \\
\end{array}$ & $\begin{array}{r}0.127 \\
(0.580) \\
\end{array}$ & $\begin{array}{r}1.91 \\
(3.040) \\
\end{array}$ \\
\hline$g r$ & $\begin{array}{r}-0.633 \\
(0.612) \\
\end{array}$ & $\begin{array}{r}0.328 \\
(1.298) \\
\end{array}$ & $\begin{array}{r}-0.889 * * \\
(0.351) \\
\end{array}$ & $\begin{array}{r}-0.187 \\
(0.738) \\
\end{array}$ & $\begin{array}{r}-2.378 \\
(1.443) \\
\end{array}$ \\
\hline$s$ & $\begin{array}{r}0.513 \\
(0.525) \\
\end{array}$ & $\begin{array}{r}0.859 \\
(0.797) \\
\end{array}$ & $\begin{array}{r}-0.754 * * \\
(0.343) \\
\end{array}$ & $\begin{array}{r}-0.867 \\
(0.594) \\
\end{array}$ & $\begin{array}{r}-2.118 \\
(1.619) \\
\end{array}$ \\
\hline $\inf$ & $\begin{array}{r}0.361 \\
(0.277) \\
\end{array}$ & $\begin{array}{r}0.516 \\
(0.391) \\
\end{array}$ & $\begin{array}{r}-0.119 \\
(0.124) \\
\end{array}$ & $\begin{array}{r}0.028 \\
(0.212) \\
\end{array}$ & $\begin{array}{r}0.565 \\
(1.069) \\
\end{array}$ \\
\hline $\operatorname{tr}$ & $\begin{array}{r}-1.270 \\
(0.750) \\
\end{array}$ & $\begin{array}{r}-2.183^{* *} \\
(0.919) \\
\end{array}$ & $\begin{array}{r}0.888^{* * * *} \\
(0.281) \\
\end{array}$ & $\begin{array}{r}1.290^{* *} \\
(0.481) \\
\end{array}$ & $\begin{array}{r}2.004 \\
(2.592) \\
\end{array}$ \\
\hline c & $\begin{array}{r}0.401 \\
(0.230)\end{array}$ & $\begin{array}{r}0.566^{* *} \\
(0.241)\end{array}$ & $\begin{array}{r}0.075 \\
(0.141)\end{array}$ & $\begin{array}{r}0.149 \\
(0.178)\end{array}$ & $\begin{array}{r}-0.031 \\
(0.333)\end{array}$ \\
\hline Trend & & & & $\begin{array}{r}-0.008^{* *} \\
(0.003) \\
\end{array}$ & \\
\hline Model Tanı Testleri & \multicolumn{5}{|c|}{ Test Istatistikleri } \\
\hline Breusch- Godfrey LM testi & $\begin{array}{l}0.070 \\
(0.932)\end{array}$ & $\begin{array}{l}1.821 \\
(0.193)\end{array}$ & $\begin{array}{l}1.322 \\
(0.290)\end{array}$ & $\begin{array}{l}0.420 \\
(0.666)\end{array}$ & $\begin{array}{l}2.744 \\
(0.177)\end{array}$ \\
\hline Değişen Varyans testi: BPG & $\begin{array}{l}0.687 \\
(0.780) \\
\end{array}$ & $\begin{array}{l}1.603 \\
(0.166) \\
\end{array}$ & $\begin{array}{l}0.672 \\
(0.767) \\
\end{array}$ & $\begin{array}{l}0.416 \\
(0.964) \\
\end{array}$ & $\begin{array}{l}3.240 \\
(0.073) \\
\end{array}$ \\
\hline$J-B$ Normality test & $\begin{array}{l}2.930 \\
(0.231)\end{array}$ & $\begin{array}{l}1.112 \\
(0.573)\end{array}$ & $\begin{array}{l}5.931 \\
(0.051)\end{array}$ & $\begin{array}{l}0.606 \\
(0.738)\end{array}$ & $\begin{array}{l}0.709 \\
(0.701)\end{array}$ \\
\hline Ramsey-Reset testi & $\begin{array}{l}0.060 \\
(0.952)\end{array}$ & $\begin{array}{l}2.379 \\
(0.124)\end{array}$ & $\begin{array}{l}1.919 \\
(0.069)\end{array}$ & $\begin{array}{l}0.406 \\
(0.691)\end{array}$ & $\begin{array}{l}1.451 \\
(0.206)\end{array}$ \\
\hline
\end{tabular}

Not: Uygun model seçimi Akaike bilgi kriterine göre yapılmaktadır. Katsayılara ait standart hatalar parantez içerisinde yer almakta ve $* * *, * *, *$ sirasıyla $\% 1, \% 5$ ve $\% 10$ düzeyinde istatistiksel olarak anlamlıllğı göstermektedir. Model tanı testlerinin olasılık değerleri parantez içerisinde gösterilmektedir.

Türkiye gibi sermaye akışının ani bir şekilde kesildiği, döviz kuru dalgalanmaları ya da politik ve jeopolitik risklerden kaynaklı olarak ortaya çıkabilen makroekonomik şokların yaygın ve etkilerinin daha şiddetli olduğu ülkelerde bankaların böylesi belirsizlik ortamlarında daha az risk alan davranışlar sergilemesi daha olası görünmektedir. Diğer bir ifadeyle bankaların risksiz varlıklar olarak adlandırılan devlet tahvillerine ağırlık vermeleri bankaların karlılıklarındaki oynaklığı azaltarak banka iflaslarının önüne geçebilir. Bu durum finansal sistemde ortaya çıkabilecek derin aksaklıkların oluşmasını engelleyerek finansal istikrar ve dolayısıyla makroekonomik istikrara katkı sağlayabilir. Dolayısıyla burada elde edilen bulgular Türkiye'de kamu iç borçlarının finansal gelişmeyi dışlamadığı ve aksine gelişimine katkı sağladığı şeklindeki güvenli varlıklar görüşü lehine kanttlar içermektedir.

Diğer yandan yüksek enflasyon dönemlerinde bankaların varlıklarında likidite avantajlarından dolayı devlet tahvillerine ağırlık vermeleri olası bir davranıştır. Yüksek enflasyon dönemlerinde iktisadi aktörlerin fiyatlama davranışları özellikle uzun dönemde daha fazla belirsizlik içerdiğinden böylesi bir belirsizlik ortamında bankalar tuttukları varlıkları vade bakımından kısaltma eğiliminde olabilir. Yine bu eylemler bankaların risk alma davranışlarını azalttıkları şeklinde yorumlanabilir ve dolayısıyla finansal istikrarsızlığın ana nedenlerinin başında yer alan banka iflaslarının ortaya çıkma olasılı̆̆ını azaltabilir. Finansal sistemde istikrarsızlıkların azalması ise özellikle hanehalkı tarafindan finansal sisteme duyulan güvenin artması ve böylece hanehalklarının finansal piyasalara katılımlarını sağlayabilir.

De Soto (2000) birçok ülkede teminat kısıtlarının finansal gelişme önünde önemli engeller yarattığını vurgulamaktadır. Bu çerçevede kamu iç borcundaki artışların teminatları daha likit hale getirerek finansal gelişmeye katkıda bulunabileceği söylenebilir. Bu açıdan bakıldı̆̆ında devlet tahvillerini elinde tutan hanehalkının, şirket ve bankaların finansman ihtiyaçları sırasında bu varlıkları teminat olarak gösterebilmesi mümkün olmaktadır. Taşınır ya da taşınmaz varlıkların teminat olarak gösterilmesi yerine böylesi daha likit varlıkların teminat olarak gösterilmesi iktisadi aktörlerin krediye ulaşımını kolaylaştırarak kredi piyasalarını ve dolayısıyla finansal gelişmeyi pozitif etkileyebilir.

Diğer yandan kamu iç borcu ve finansal gelişme arasındaki pozitif ilişki mevduat ve tasarruflar cephesinden de ortaya çıkabililir. Finansal kurumların güvenli varlıklar olan devlet tahvillerine yönelerek karlılıklarını artırması onların bilançolarında bir iyileşmeyi beraberinde getirecektir. Finansal sistemin özelliklede bankaların karlılığı ve istikrarındaki artışlar mevduat sahiplerinin fon fazlasını finansal sisteme arz etme konusunda daha istekli olmasına yol açabilir (Kumhof ve Tanner, 2005). Dolayısıyla kamu borcundaki artışlar iktisadi aktörlerin tasarruf fazlasını finansal sistemde değerlendirme oranını artırırken bu tasarruf artışı da uzun dönemde reel faiz oranlarını düşürebilirken borçlanmanın 
vadesini uzatabilir. Tersi bir durum mevduat sahiplerini caydırabilir ya da daha yüksek faiz talep etmelerine yol açabilir. Faiz oranlarındaki düşüşler ve halkın finansal varlıklarındaki bu artışların teminatlar üzerindeki etkileri ile beraber kredi maliyetlerini azaltarak kredi piyasalarının gelişimine katkı sağlayabilmektedir.

Tablo 6. Hata Düzeltme Modeli ve Kısa Dönem Katsayı Tahminleri

\begin{tabular}{|c|c|c|c|c|c|c|c|c|}
\hline \multirow{3}{*}{$\begin{array}{l}\text { Bağımsız } \\
\text { Değişken }\end{array}$} & \multicolumn{8}{|c|}{ Bağımlı Değişken } \\
\hline & \multicolumn{2}{|l|}{$f d$} & \multicolumn{2}{|c|}{ fi } & \multicolumn{2}{|l|}{$f m$} & \multicolumn{2}{|c|}{ fid } \\
\hline & Katsayl & $\begin{array}{l}\text { Std. } \\
\text { Hata }\end{array}$ & Katsayl & $\begin{array}{l}\text { Std. } \\
\text { Hata }\end{array}$ & Katsayl & $\begin{array}{l}\text { Std. } \\
\text { Hata }\end{array}$ & Katsayl & $\begin{array}{l}\text { Std. } \\
\text { Hata }\end{array}$ \\
\hline$\Delta f d(-1)$ & & & & & & & $-1.057 * * *$ & 0.271 \\
\hline$\Delta f d(-2)$ & & & & & & & $-0.589 * *$ & 0.262 \\
\hline$\Delta p d$ & -0.189 & 0.180 & $-0.892 * * *$ & 0.267 & -0.169 & 0.553 & $0.290 * *$ & 0.110 \\
\hline$\Delta p d(-1)$ & $-0.434 * *$ & 0.163 & 0.188 & 0.255 & -0.526 & 0.419 & -0.015 & 0.100 \\
\hline$\Delta p d(-2)$ & & & $0.868 * * *$ & 0.222 & $-0.915^{*}$ & 0.444 & $0.198 *$ & 0.098 \\
\hline$\Delta p d(-3)$ & & & $-1.070 * * *$ & 0.189 & 0.620 & 0.447 & $-0.110^{*}$ & 0.058 \\
\hline$\Delta g r$ & $-0.262 * *$ & 0.093 & $-0.452 * * *$ & 0.143 & $-0.858 * *$ & 0.336 & $0.182 * *$ & 0.074 \\
\hline$\Delta g r(-1)$ & 0.106 & 0.085 & $-0.299 * *$ & 0.116 & 0.428 & 0.230 & $-0.125^{* *}$ & 0.052 \\
\hline$\Delta g r(-2)$ & $-0.260 * * *$ & 0.069 & 0.050 & 0.089 & $-0.739 * * *$ & 0.188 & & \\
\hline$\Delta g r(-3)$ & & & 0.096 & 0.080 & & & & \\
\hline$\Delta s$ & $0.166^{* *}$ & 0.070 & 0.021 & 0.096 & 0.325 & 0.192 & $-0.093^{*}$ & 0.044 \\
\hline$\Delta s(-1)$ & 0.158 & 0.097 & $-0.210 *$ & 0.110 & 0.301 & 0.280 & $0.130 * *$ & 0.043 \\
\hline$\Delta s(-2)$ & $0.402^{* * *}$ & 0.105 & & & $1.117 * * *$ & 0.308 & -0.064 & 0.052 \\
\hline$\Delta s(-3)$ & $0.550 * * *$ & 0.121 & & & $0.640 *$ & 0.272 & $0.138 * *$ & 0.052 \\
\hline$\Delta i n f$ & $0.076^{*}$ & 0.042 & $-0.240 * * *$ & 0.056 & 0.180 & 0.118 & -0.002 & 0.028 \\
\hline $\operatorname{\Delta inf}(-1)$ & $-0.154 * * *$ & 0.045 & $-0.328 * * *$ & 0.050 & -0.133 & 0.096 & $-0.043^{*}$ & 0.022 \\
\hline $\operatorname{\Delta inf}(-2)$ & & & & & -0.086 & 0.123 & 0.008 & 0.019 \\
\hline $\operatorname{\Delta inf}(-3)$ & & & & & -0.071 & 0.050 & $0.023^{*}$ & 0.007 \\
\hline$\Delta t r$ & $0.273^{* *}$ & 0.108 & 0.068 & 0.084 & $0.825 * *$ & 0.332 & 0.008 & 0.040 \\
\hline$\Delta t r(-1)$ & $0.530 * * *$ & 0.113 & $0.798 * * *$ & 0.117 & $0.574 * *$ & 0.235 & & \\
\hline$\Delta t r(-2)$ & -0.051 & 0.091 & 0.104 & 0.113 & $-0.459 *$ & 0.226 & & \\
\hline$\Delta t r(-3)$ & -0.071 & 0.069 & & & -0.440 & 0.238 & & \\
\hline Dtrend & $0.006 * * *$ & 0.001 & 0.004 & 0.002 & -0.008 & 0.005 & $-0.002 *$ & 0.001 \\
\hline $\operatorname{ECM}(-1)$ & $-1.202 * * *$ & 0.184 & $-0.408 * * *$ & 0.105 & $-1.229 * * *$ & 0.263 & $0.349 *$ & 0.160 \\
\hline
\end{tabular}

Not: $* * *, * *, *$ sirasıyla $\% 1, \% 5$ ve $\% 10$ düzeyinde istatistiksel olarak anlamlılığı göstermektedir. fd bağımsız değişkenleri finansal gelişme endeksi ve alt endekslerini temsil etmektedir.

Tablo 7. Hata Düzeltme Modeli ve Kısa Dönem Katsayı Tahminleri (Devam)

\begin{tabular}{|c|c|c|c|c|c|c|c|c|c|c|}
\hline \multirow{3}{*}{$\begin{array}{l}\text { Bağımsız } \\
\text { Değişken }\end{array}$} & \multicolumn{10}{|c|}{ Bağımlı Değiş̧ken } \\
\hline & \multicolumn{2}{|c|}{ fia } & \multicolumn{2}{|c|}{ fie } & \multicolumn{2}{|c|}{$f m d$} & \multicolumn{2}{|c|}{ fma } & \multicolumn{2}{|c|}{ fme } \\
\hline & Katsayl & $\begin{array}{l}\text { Std. } \\
\text { Hata }\end{array}$ & Katsayı & $\begin{array}{l}\text { Std. } \\
\text { Hata }\end{array}$ & Katsayı & $\begin{array}{l}\text { Std. } \\
\text { Hata }\end{array}$ & Katsayl & $\begin{array}{l}\text { Std. } \\
\text { Hata }\end{array}$ & Katsayl & $\begin{array}{l}\text { Std. } \\
\text { Hata }\end{array}$ \\
\hline$\Delta f d(-1)$ & $0.320^{* *}$ & 0.139 & & & & & 0.004 & 0.173676 & 0.143 & 0.414 \\
\hline$\Delta f d(-2)$ & & & & & & & $-0.385^{* *}$ & 0.171430 & 0.435 & 0.284 \\
\hline$\Delta p d$ & $-0.473 * *$ & 0.214 & -1.158 & 0.730 & 0.048 & 0.303 & -0.336 & 0.365715 & 0.355 & 1.477 \\
\hline$\Delta p d(-1)$ & -0.075 & 0.130 & & & & & & & $-2.936^{*}$ & 1.359 \\
\hline$\Delta p d(-2)$ & $0.346 * *$ & 0.147 & & & & & & & $-3.092 *$ & 1.358 \\
\hline$\Delta p d(-3)$ & $-0.567 * * *$ & 0.113 & & & & & & & $3.640 * *$ & 1.100 \\
\hline$\Delta g r$ & -0.126 & 0.108 & -0.673 & 0.413 & -0.371 & 0.224 & $-0.564 * *$ & 0.222156 & -1.295 & 0.824 \\
\hline$\Delta g r(-1)$ & & & -0.360 & 0.343 & & & -0.088 & 0.169110 & 1.456 & 0.751 \\
\hline$\Delta g r(-2)$ & & & $-0.790 * *$ & 0.311 & & & $-0.450^{* *}$ & 0.160884 & $1.978^{* * *}$ & 0.515 \\
\hline$\Delta g r(-3)$ & & & & & & & & & -0.338 & 0.523 \\
\hline$\Delta s$ & 0.102 & 0.112 & -0.010 & 0.375 & 0.025 & 0.273 & 0.064 & 0.172359 & 0.967 & 0.629 \\
\hline$\Delta s(-1)$ & & & & & 0.305 & 0.275 & 0.202 & 0.202604 & 0.994 & 1.128 \\
\hline$\Delta s(-2)$ & & & & & $0.520^{* *}$ & 0.249 & 0.320 & 0.189155 & $2.494 * * *$ & 0.614 \\
\hline$\Delta s(-3)$ & & & & & & & & & 1.276 & 0.865 \\
\hline$\Delta \inf$ & $-0.143 * * *$ & 0.045 & -0.058 & 0.158 & -0.111 & 0.116 & -0.095 & 0.076990 & $0.831^{* *}$ & 0.311 \\
\hline $\operatorname{\Delta inf}(-1)$ & $-0.106 * * *$ & 0.031 & $0.563 * * *$ & 0.161 & & & 0.019 & 0.082259 & 0.200 & 0.381 \\
\hline
\end{tabular}




\begin{tabular}{|c|c|c|c|c|c|c|c|c|c|c|}
\hline $\operatorname{\Delta inf}(-2)$ & -0.051 & 0.034 & 0.086 & 0.079 & & & $\begin{array}{r}- \\
0.148^{* * *}\end{array}$ & 0.040764 & -0.524 & 0.448 \\
\hline $\operatorname{\Delta inf}(-3)$ & $0.044 * *$ & 0.015 & & & & & & & & \\
\hline$\Delta t r$ & 0.069 & 0.076 & 0.227 & 0.298 & 0.426 & 0.252 & $0.511^{* * *}$ & 0.159941 & 0.807 & 0.989 \\
\hline$\Delta \operatorname{tr}(-1)$ & 0.121 & 0.092 & $1.615^{* * *}$ & 0.387 & 0.295 & 0.254 & -0.335 & 0.197159 & 0.355 & 1.308 \\
\hline$\Delta \operatorname{tr}(-2)$ & $0.267 * * *$ & 0.083 & & & $0.751^{* * *}$ & 0.191 & & & 0.242 & 0.999 \\
\hline$\Delta \operatorname{tr}(-3)$ & $-0.168 * *$ & 0.069 & & & & & & & -0.844 & 0.436 \\
\hline$\Delta$ trend & & & & & & & $-0.004 * *$ & 0.001923 & & \\
\hline$\overline{E C M(-1)}$ & $-0.190 * * *$ & 0.047 & $0.709^{* * *}-$ & 0.163 & $0.930^{* * *}$ & 0.165 & $\begin{array}{r}- \\
0.598 * * *\end{array}$ & 0.158595 & $-1.234^{* *}$ & 0.379 \\
\hline
\end{tabular}

Not: ***, **, * siraslyla \%1, \%5 ve \%10 düzeyinde istatistiksel olarak anlamlllı̆̆l göstermektedir.

Ekonomik büyümenin finansal gelişmeyi pozitif etkilediğini ileri süren Robinson (1952) ve Patrick (1966)'in aksine ekonomik büyüme değişkeninin anlamlı olduğu modellerde katsayılar beklenenin tersine negatif olarak elde edilmektedir. Bunun yanı sıra tasarruf oranı değişkenine ait katsayıların istatistiksel olarak anlamlı olduğu modellerin çoğunda finansal gelişme üzerindeki etkisinin beklenenin aksine negatif olduğu da görülmektedir. Tasarruflar ve ekonomik büyümenin finansal gelişmeyi olumsuz etkilemesi gelir dağılımı adaletsizliğinin yüksek olduğu ülkelerde ortaya çıkabilmektedir. Bu ülkelerde toplam gelirden düşük pay alan bireyler genellikle ekonomik büyümeden beklenen faydayı elde edemeyebilirler. Aynı şekilde bu grupların tasarruf miktarını artırabilecek kaynakları da sınırlıdır. Dolayısıyla gelir dağılımındaki bozulmaların hızlı olduğu durumlarda; yüksek gelir grubundakilerin marjinal tasarruf eğilimleri yüksek olduğundan ekonomik büyümeden aldıkları pay ve toplam tasarruf miktarı içindeki payları giderek artmaktadır. Artan tasarruf ise bu gruplara yapılan ödemeler ve dolayısıyla refah artışını hızlandırmaktadır. Bu koşullar altında finansal sistemin tabana yayılması, geniş kitlelere ulaşması ve bu kitlelerin ihtiyaç duyduğu finansal ürünleri geliştirebilmesi olanaklı olamayabilir. Diğer bir açıklayıcı değişken olan enflasyonun ise temel finansal gelişme endeksi üzerindeki etkisi anlamlı ve pozitiftir; dolayısıyla enflasyon oranı arttıkça finansal gelişmede iyileşme beklenmektedir. Ancak diğer yandan enflasyonun finansal gelişmenin alt endeksleri üzerindeki etkisi genel olarak anlamsızdır. Son olarak dış ticaret açığının temel finansal gelişme göstergesi üzerinde anlamlı etkisinin olduğu söylenemezken; finansal gelişmenin alt endeksleri üzerindeki etkisinin ise kullanılan bağımsız değişkene göre farklılaştığı söylenebilir dolayısıyla net etkileri tespit edilememektedir.

Tablo 7 tahmin edilen modellerin kısa dönem katsayıları ile hata düzeltme modeline ait sonuçları göstermektedir. Hata düzeltme katsayısı finansal kurumlar derinlik endeksi için kurulan model hariç negatif ve anlamlıdır dolayısıyla ilgili değişkenler arasında uzun dönemli bir ilişkinin olduğu söylenebilir. Diğer bir ifadeyle kısa dönemde yaşanan şokların uzun dönemde giderilebildiğini de göstermektedir. Hata düzeltme teriminin katsayısı meydana gelecek bir şokun etkisinin bir sonraki dönemde yüzde kaç hızla dengeye geleceğini göstermektedir. Bağımlı değişken olarak finansal kurumlar derinlik endeksi kullanılan modelde ise eşbütünleşme ilişkisi bulunamamıştır; dolayısıyla bu sonuçları yorumlamak yanıltıcı olabilmektedir.

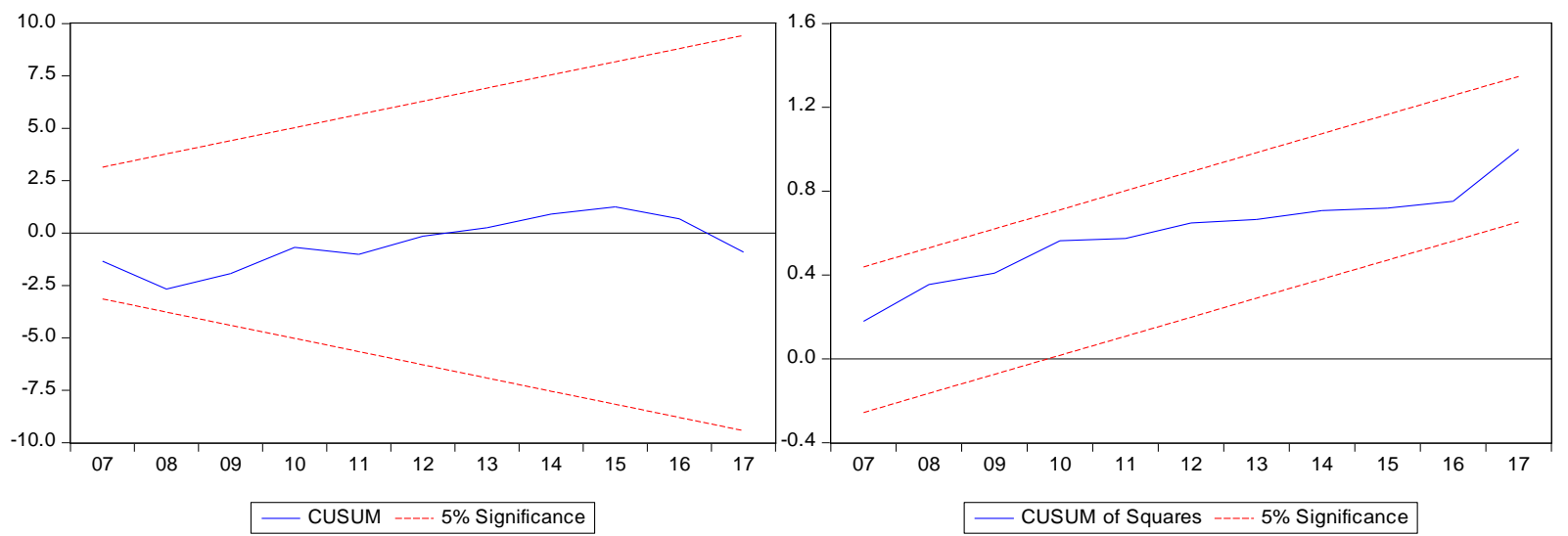

Şekil 1. Fd Model Cusum ve Cusum² Testleri 
Sekmen, T., Doğan, E., Topuz, S. G. / Journal of Yasar University, 2020, 15/59, 544-559
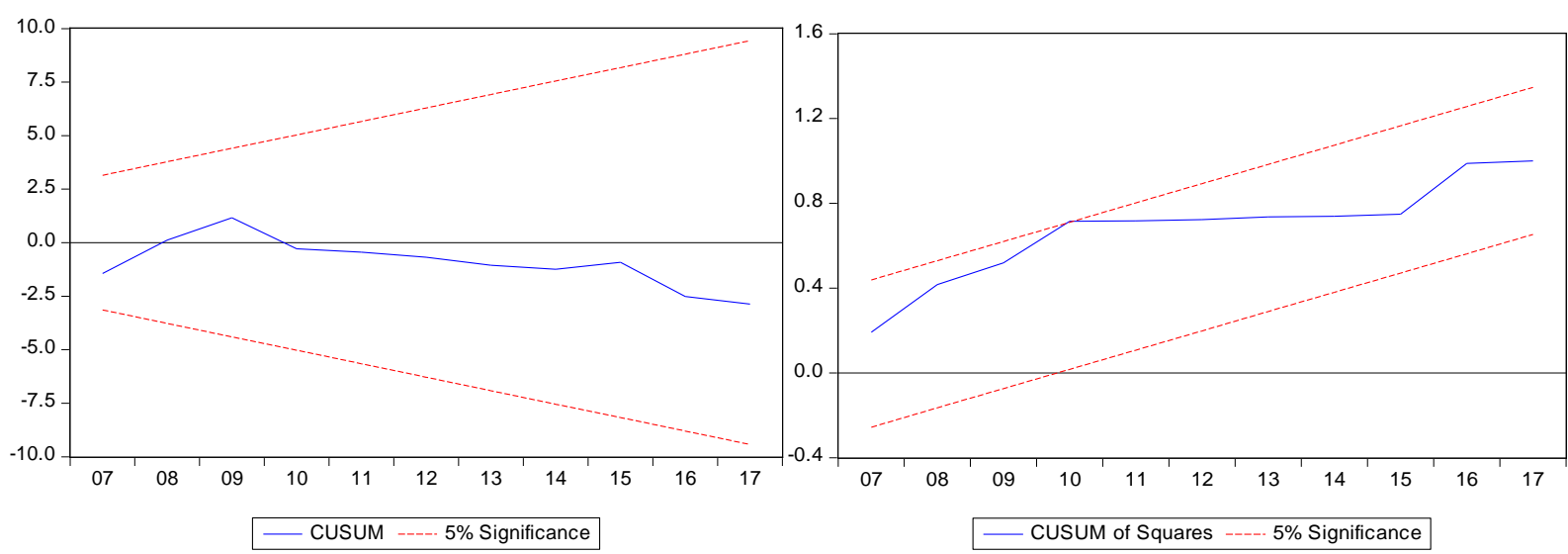

Şekil 2. Fi Model Cusum ve Cusum² Testleri
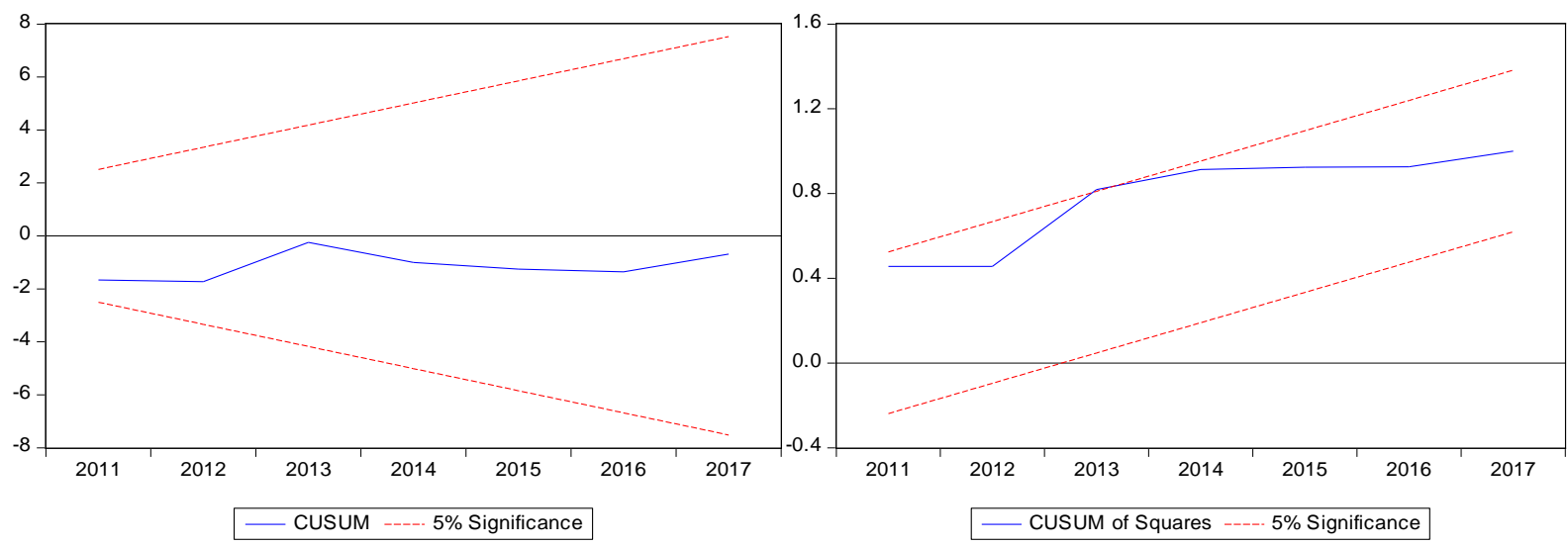

Şekil 3. Fm Model Cusum ve Cusum² Testleri

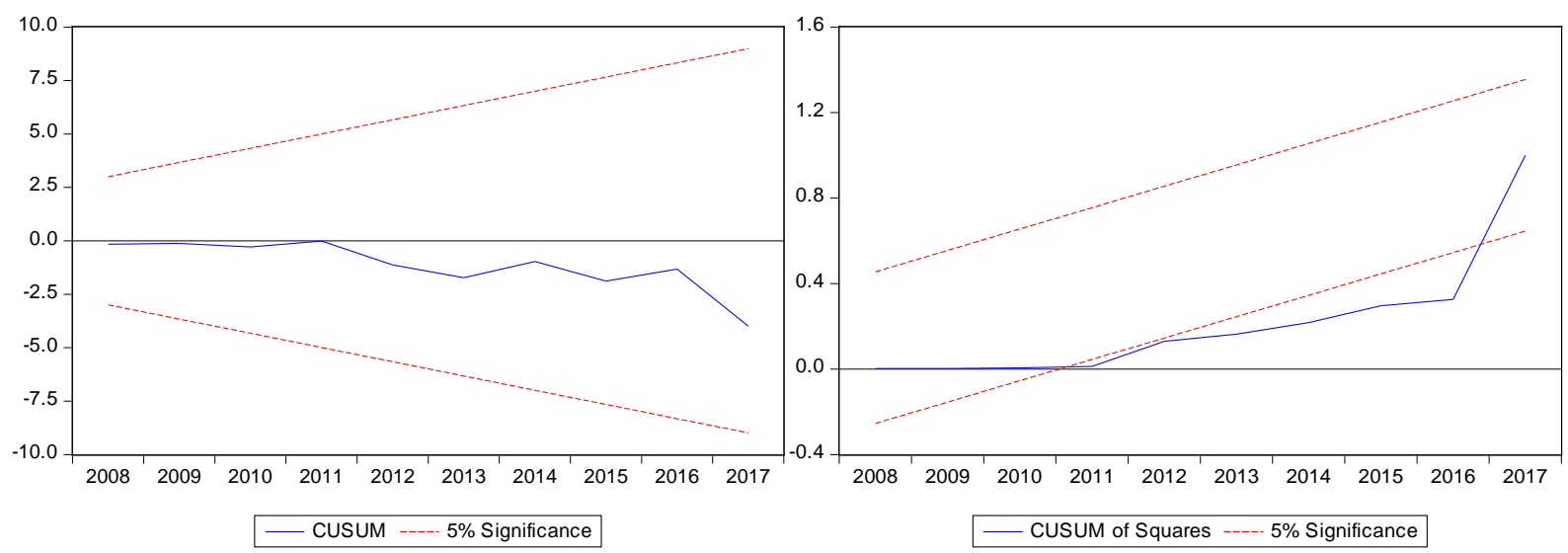

Şekil 4. Fid Model Cusum ve Cusum² Testleri 
Sekmen, T., Doğan, E., Topuz, S. G. / Journal of Yasar University, 2020, 15/59, 544-559
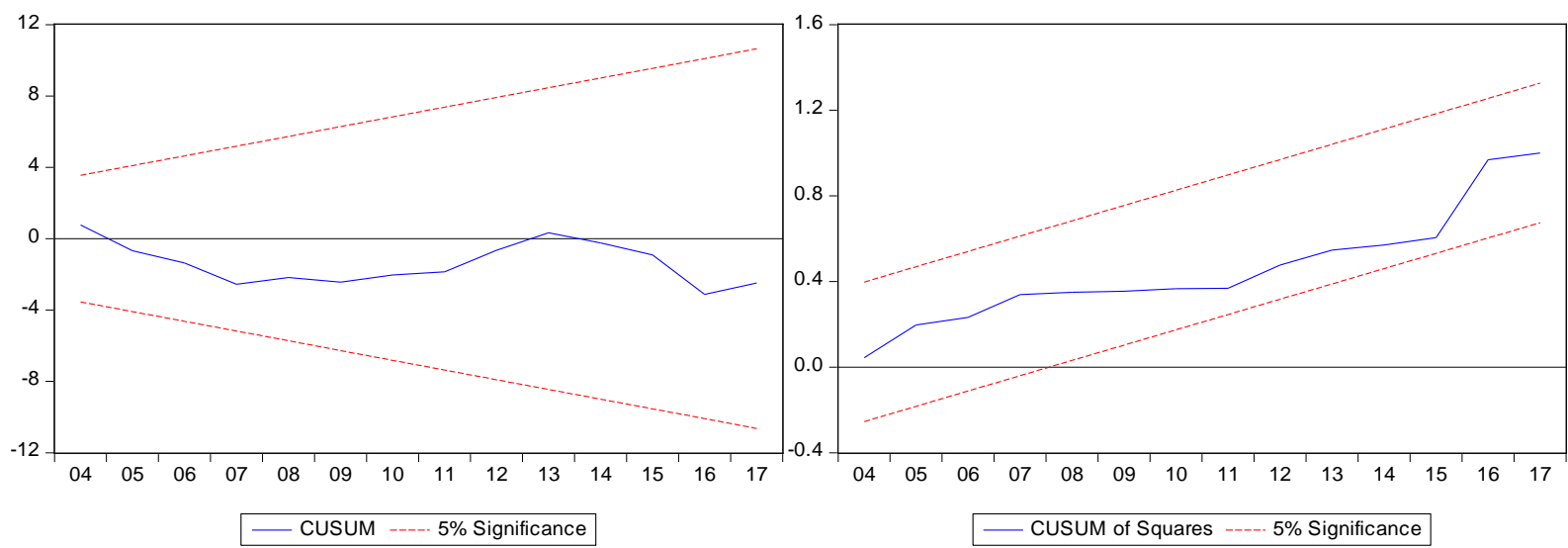

Şekil 5. Fia Model Cusum ve Cusum² Testleri
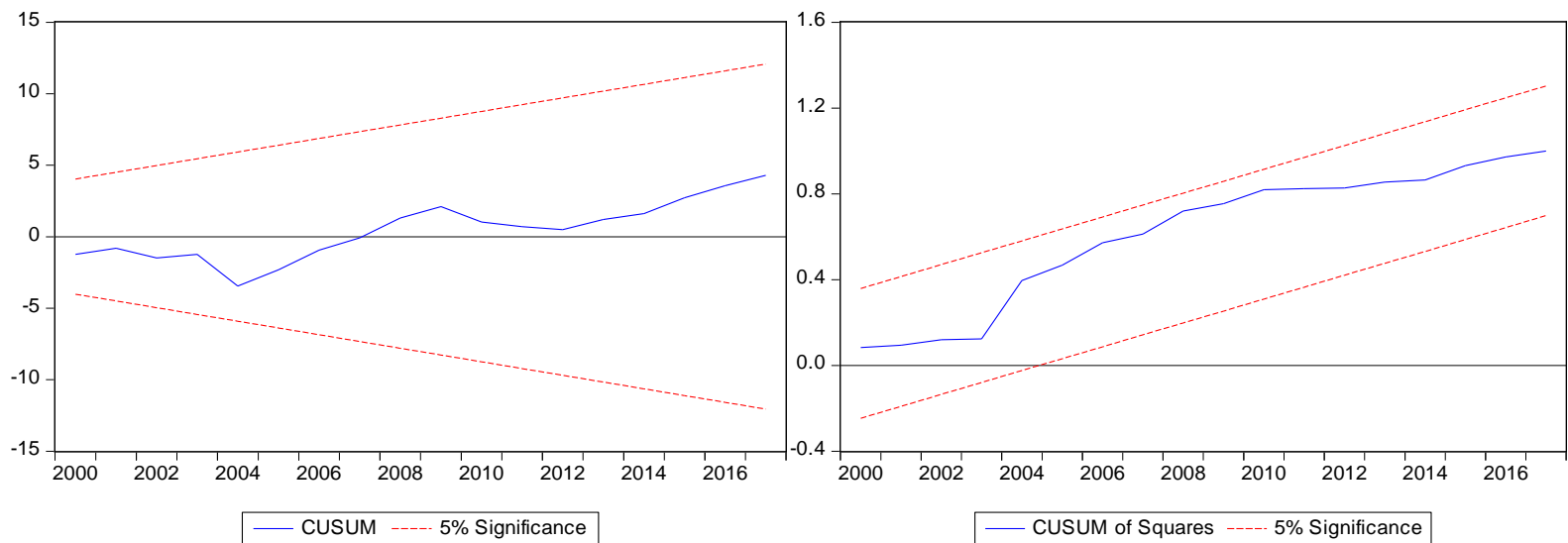

Şekil 6. Fie Model Cusum ve Cusum² Testleri

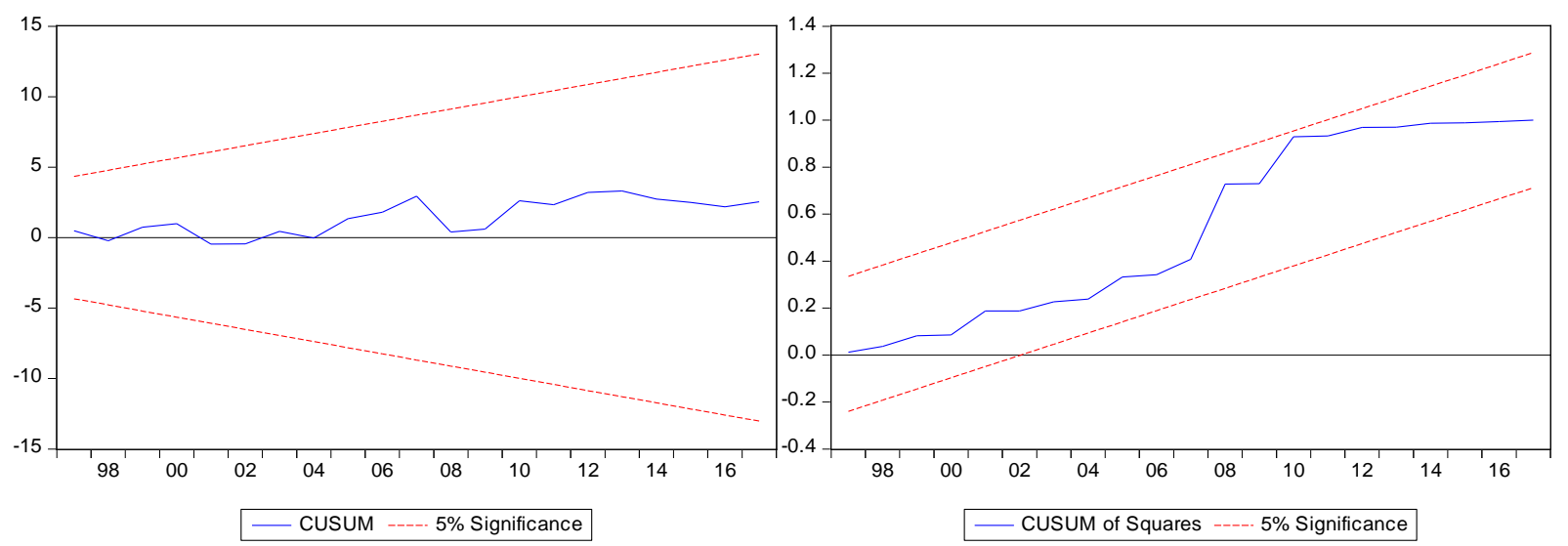

Şekil 7. Fmd Model Cusum ve Cusum² Testleri
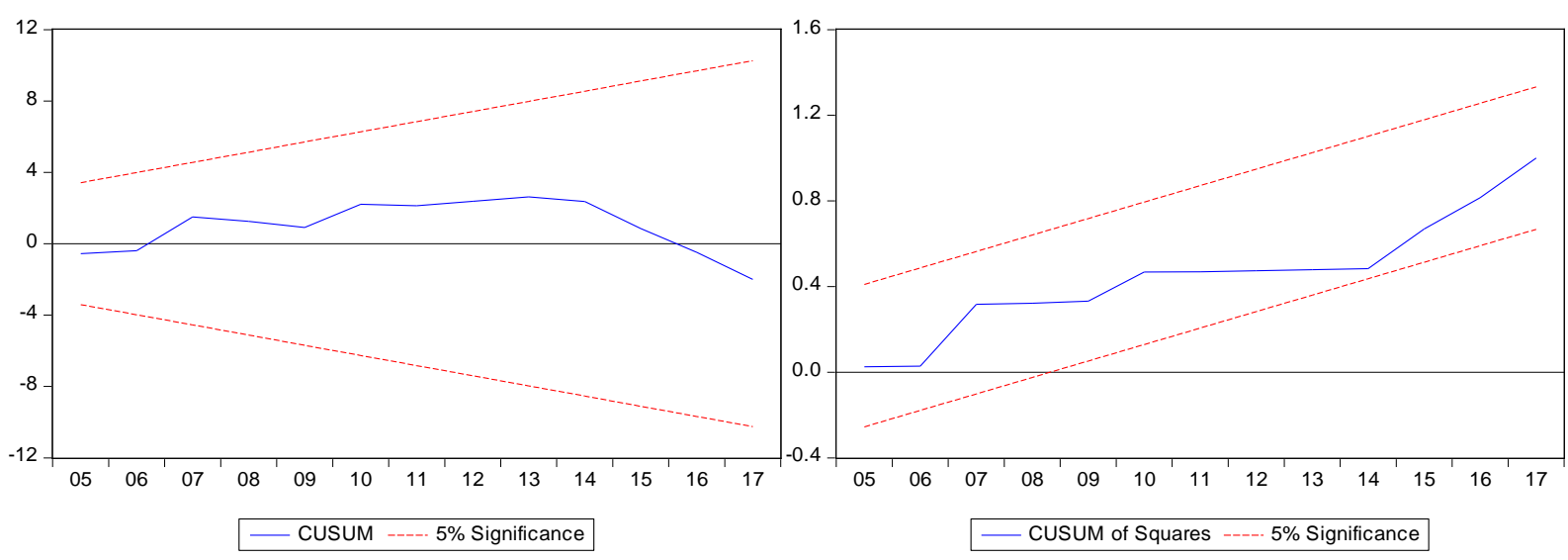
Şekil 8. Fma Model Cusum ve Cusum² Testleri

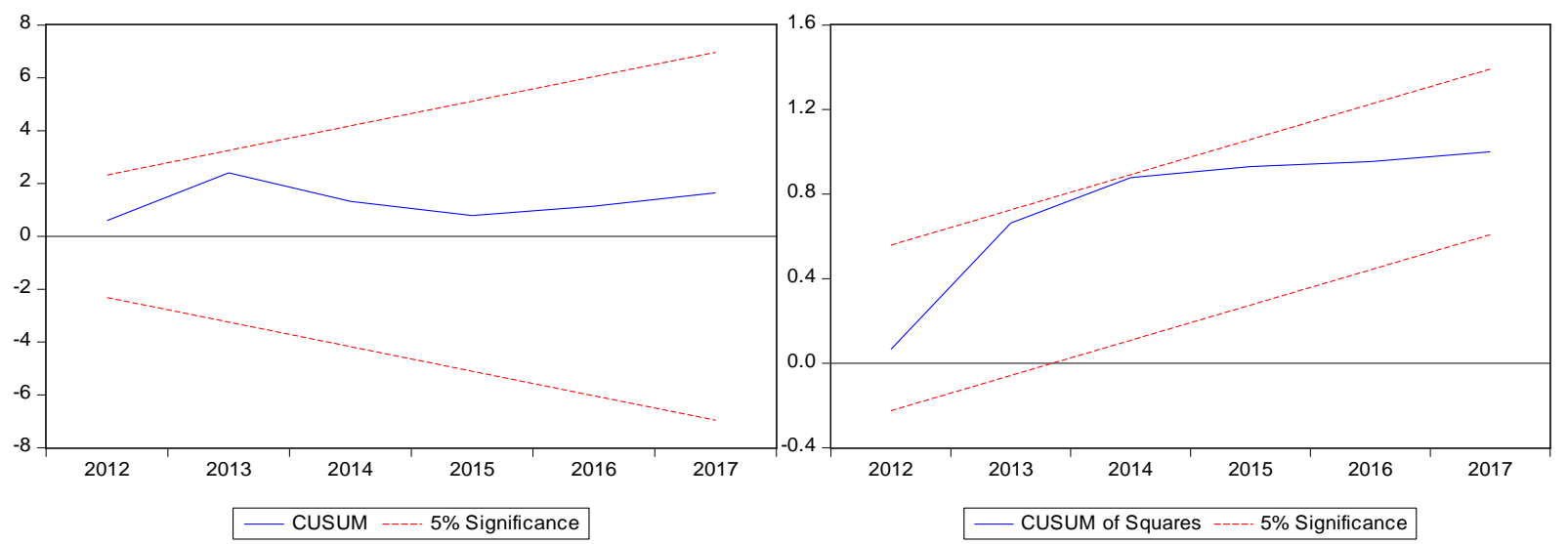

Şekil 9. Fme Model Cusum ve Cusum² Testleri

Şekil 1- 9'da verilen ve Brown vd. (1975) tarafindan geliştirilen Cusum ve Cusum² test sonuçları ise diğer tahmin sonuçlarına benzer olarak yalnızca bağımlı değişkeni finansal kurumlar derinlik endeksi olan model hariç katsayıların \%5 kritik sınırlar içerisinde kaldığını, herhangi bir yapısal kırılma olmadığını ve istikrarlı olduğunu göstermektedir.

\section{Sonuç}

Türkiye ekonomisinde 1980’li yıllarda oluşmaya ve 2000'li yıllarda derinleşmeye başlayan finansal piyasalar günümüzde büyük oranda uluslararası finansal piyasalar ile entegre hale gelmiştir. Büyük oranda dış gelişmeler ve uluslararası sermaye akışlarındaki artışlar gibi faktörler tarafından tetiklenen bu gelişme süreci ulusal ve uluslararası makroekonomi politikalardan sıklıkla etkilenmektedir. Bu gelişme sürecini etkileyen makroekonomi politikaları içinde her ne kadar para politikalarının etkisi daha büyük olsa da finansal gelişme ülkelerin maliye politikalarına ilişkin gelişmelerin etkisinden bağımsız düşünülmemelidir. Etkin bir para politikası uygulanabilmesi için derinleşmiş bir tahvil piyasasına ihtiyaç duyulurken bu piyasasının oluşumu ülkenin tahvil stokundaki yükseliş diğer bir ifadeyle kamu iç borcundaki artış ile gerçekleşebilmektedir. Dolayısıyla kamu iç borçlarındaki artışlar ülkenin tahvil piyasasının derinleşmesinin göstergelerinden biri olarak görülebilir. Ancak daha önce ifade edildiği gibi; farklı bir akıl yürütme ile bankaların yoğun bir biçimde kamu varlıkları edinmesi, finansal gelişmenin unsurlarından yalnızca biri olan tahvil piyasasının gelişimine katkı sağlayabilir. Bu durum finansal ürün çeşitliliğinin artmasını engelleyebilir ve özellikle de daha geniş kitlelerin ihtiyaç duyduğu farklı türdeki finansal varlıkların geliştirilmesinin önüne geçerek finansal piyasaların derinleşmesini ve gelişmesini yavaşlatabilir.

Bu çalışma yukarıda bahsedildiği üzere Türkiye'de kamu iç borcundaki artan trendin finansal gelişme sürecini nasıl etkilediğini anlamamıza yardımcı olmaktadır. 1980-2017 dönemine ilişkin verilerin ARDL model aracılığıyla analiz edilmesi sonucunda kamu iç borç düzeyi ile finansal gelişme arasında uzun dönemde pozitif bir iliş̧ki bulunduğu tespit edilmektedir. Bu sonuç bankaların devlet tahvilleri gibi güvenli varlıklar tutarak finansal gelişmeyi yavaş ve istikrarlı bir biçimde artırdığı "güvenli varlıklar" görüşünü destekler niteliktedir. Ulaşılan bu sonuç literatür kapsamında yer alan Türkiye'ye ilişkin ampirik çalışmalardan elde edilen sonuçlardan farklılık göstermektedir.

Son otuz yılda Türkiye'de dahil olmak üzere gelişmiş ve gelişmekte olan ülkelerin neredeyse hepsinde hem diş hem de iç borç düzeylerinde artışlar yaşandığı belirgin bir biçimde gözlemlenmektedir. Özellikle iç borç piyasasındaki bu gelişmeler kamu finansmanının sağlanmasında dış kaynak bağımlılı̆ıının azalmasına imkan sağlamaktadır. İç borçların dış borçları tam olarak ikame etmesi henüz söz konusu olmamasına rağmen iç borçlanma piyasasındaki bu gelişmeler yurt içindeki iktisadi aktörlerin finansal sisteme yavaş yavaş daha fazla dahil olmaya başladığının göstergesi olarak yorumlanabilir. Ancak kamunun mali disiplininde ortaya çıkan bozulmalar ve sonrasında kamu finansmanında yaşanabilecek sorunların hızlı bir biçimde finansal sisteme aktarılabileceği unutulmamalıdır. Dolayısıyla iyi işleyen bir finansal sistem ve makroekonomik istikrar için mali disiplinin yanı sıra sürdürülebilir ve istikrarlı bir kamu iç borç düzeyinin önemle vurgulanması gerekir. Aksi halde kamu borcu finansal istikrarsızlığın ana kaynağı olabilir. Kamu iç borcu ve finansal gelişme ilişkisinde Türkiye için ortaya çıkan bu sonucun bir nedeni özellikle son yirmi yılda sağlanan göreli mali disiplin olabilir. Bu dönemde kamunun mali yapısında önemli bir aksaklığın yaşanmaması finansal gelişme sürecini de olumlu etkilemiş olabilir. Diğer bir olası neden ise özellikle 2001 yılında yaşanan bankacılık krizi sonrasında bankacılık sektörüne yönelik düzenlemelerin bankacılık sektöründe ve finansal piyasalarda yarattığı istikrar olarak görülebilir. Bankacılık kanunu ve uygulamalarına yönelik sıkı düzenlemelerin gerçekleştirilmesi sadece bankalar değil diğer finansal kuruluşlar aracılı̆̆ıla da finansal gelişmeyi desteklemiş olabilir.

Son olarak kamu iç borcunun finansal gelişme üzerindeki etkileri doğrusal olmayabilir. Bankacılık sektörünün finansal sistemin ana omurgasını oluşturduğu gelişmekte olan ülkeler genellikle finansal gelişmenin erken evrelerinde bulunmaktadır. Finansal gelişmenin erken aşamalarında güvenli varlıklar aracılığıyla kamu iç borcunun finansal gelişme 
Sekmen, T., Doğan, E., Topuz, S. G. / Journal of Yasar University, 2020, 15/59, 544-559

üzerindeki etkisi pozitif finansal gelişmenin ileri aşamalarında ise negatif olabilir. Şüphesiz ki gelecek çalışmalar farklı finansal gelişme düzeylerine sahip ülkeler ile karşılaştırmalı olarak böylesi bir sorgulama yaparak daha detaylı bilgi edinilmesine imkân sağlayabilir. 


\section{KAYNAKÇA}

Afonso, Antonio, \& Jalles, J.Tovar. 2017. "Sovereign Debt Effects and Composition: Evidence From Time Varying Estimates”. ISEG Economics Department Working Paper No. WP 03/2017/DE/UECE.

Altaylıgil, Y. Barış, \& Akkay, R. Can. 2013. "The Effect of the Domestic Debt on the Financial Development: A Case Study for Turkey.” International Journal of Economics and Finance, 5(5).

Beck, Thorsten. 2002. "Financial Development and International Trade: Is there a link?”. Journal of international Economics, 57(1), 107-131.

Boyd, John H., Levine, Ross \& Smith, Bruce D. 2001. “The Impact of Inflation on Financial Sector Performance”. Journal Of Monetary Economics, 47(2), 221-248.

Brown, R.L., J. Durbin, \& J.M. Evans. 1975. "Techniques for Testing The Constancy of Regression Relations Over Time.” Journal of the Royal Statistical Society, 37, 149-163.

Caballero, J. Ricardo, \& Krishnamurthy, Arvind. 2004. “Fiscal Policy and Financial Depth.” National Bureau of Economic Research, No. w10532.

Cukierman, Alex. 1991. Why Does the Fed Smooth Interest Rates? In: Belongia, M.T. (Ed.), Monetary Policy on the 75th Anniversary of the Fed. Kluwer Publishers.

De Soto, H. 2000. The Mystery of Capital: Why Capitalism Triumphs in the West and Fails Everywhere Else. Basic Books, New York, NY.

Do, Quy-Toan, \& Levchenko, Andrei A. 2004. “Trade and Financial Development”. World Bank Policy Research Working Paper, No.3347, Washington, DC.

Emran, M. Shahe, \& Farazi, Subika. 2009. "Lazy Banks? Government Borrowing and Private Credit in Developing Countries.” Institute for International Economic Policy Paper Series, WP-2009-9.

Engle, R. Fry, \& Granger, C. William 1987. "Co-Integration and Error Correction: Representation, Estimation, and Testing.” Econometrica, 251-276.

Ersoy, İmre. 2012. “Government Debt vs. Financial Depth Dilemma in Developing Countries: The case of Turkey.” Acta Oeconomica, 62(3), 345-362.

Hauner, David. 2009. "Public Debt and Financial Development.” Journal of development economics, 88(1), $171-183$.

Huybens, Elisabeth \& Smith, Bruce D. 1999. "Inflation, Financial Markets and Long-Run Real Activity.”Journal of Monetary Economics, 43(2), 283-315.

İlgün, M. Fatih. 2016. "Financial Development and Domestic Public Debt in Emerging Economies: A Panel Cointegration Analysis.” Journal of Applied Economics \& Business Research, 6(4).

İsmihan, Mustafa, \& Özkan, F. Gülçin. 2012. "Public Debt and Financial Development: A Theoretical Exploration.” Economics Letters, 115(3), 348-351.

Janda, Karel, \& Kravtsov, Oleg. 2017. "Time-varying Effects of Public Debt on the Financial and Banking Development in the Central and Eastern Europe”. MPRA Working Paper, University Library of Munich, Germany.

Johansen, Soren. 1988. “Statistical Analysis of Cointegration Vectors.” Journal of Economic Dynamics and Control, 231254.

King, G. Robert, \& Levine, Ross. 1993. "Finance and Growth: Schumpeter Might Be Right.” The quarterly journal of economics, 108(3), 717-737.

Kumhof, Michael, \& Tanner, Evan. 2005. “Government Debt: A Key Role in Financial Intermediation.” IMF Working Paper, WP/05/57.

Kutivadze, Natia. 2011. "Public debt, Domestic and External Financing, and Economic Growth." Department of Economics, Management and Quantitative Methods at Università degli Studi di Milano.

Levine, Ross. 1997. "Financial Sector Development and Economic Growth.” Journal of Economic Literature, 35(2).

Mun, M. Wei, \& Ismail, N. Wana. 2015. "The Impact of Domestic Public Debt on Financial Development in Malaysia.” International Journal of Social Science Research, 3(2), 1-19.

Patrick, Hugh T. 1966. "Financial Development and Economic Growth in Underdeveloped Countries.” Economic development and Cultural change, 14(2), 174-189.

Pesaran, M. Hashem, \& Pesaran, Bahram. 1997. Working with Microfit 4.0: Interactive. Oxford: Oxford University Press.

Pesaran, M. Hashem, Shin, Yongcheaol \& Smith, J. Richard. 2001. "Bounds Testing Approaches to the Analysis of Level Relationships.” Journal of Applied Econometrics, 289-326.

Rajan, Raghuram, \& Zingales, Luigi. 1998. “Financial Development and Growth.” American Economic Review, 88(3), 559-586.

Rajan, Raghuram, \& Zingales, Luigi. 2003. “The Great Reversals: The Politics of Financial Development in the Twentieth Century.” Journal of Financial Economics, 69(1), 5-50.

Robinson, Joan. 1952. The Generalization of the General Theory, the Rate of Interest and Other Essays. Macmillan, London, 67-142.

Rousseau, Peter L. \& Wachtel, Paul. 2001. "Inflation, financial development and growth.” In: Economic Theory, Dynamics and Markets. Springer, Boston, MA, 309-324.

Svirydzenka, Katsiaryna. 2016. Introducing a New Broad-Based Index of Financial Development. International Monetary Fund. 
Sekmen, T., Doğan, E., Topuz, S. G. / Journal of Yasar University, 2020, 15/59, 544-559

Voghouei, Hatra, Azali, M., \& Jamali, Mohammad Ali. A. 2011. “A survey of the Determinants of Financial Development.” Asian-Pacific Economic Literature, 25(2), 1-20.

Yılmaz, Fırat. 2017. “Türkiye'de Bankaların Portföylerindeki Devlet Borçlanma Senetlerinin Özel Kesim Kredilerine Etkisi.” Türkiye Cumhuriyet Merkez Bankası Uzmanlık Yeterlik Tezi. 